\title{
MBSIR $86-3348$
}

\section{Vaporization and Phase Equllbria of Simulated Radionudides}

E.f. Plante ard J.W. Hastie

US. DEPARTMENT OF COMMERCE

National Zureau of Standards

Iroritute for Watsigls Science end Engineering

High Temperature Chemistrv

Ceramics Evision

Gathersourg, MO 20890

\section{FIE COPY \\ DO HOT REMOUE}

jandary : 988

Inserim Peosit

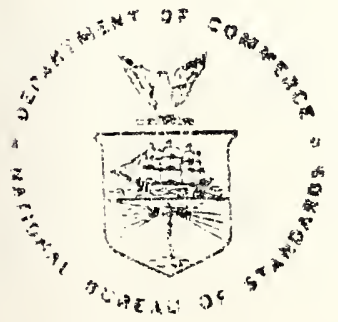

i. S. DEPARTMENT OF COMAERGE

WATIONAL SUGEAU OF STANDABST 

NBSIR $86-3348$

VAPORIZATION AND PHASE EQUILIBRIA

OF SIMULATED RADIONUCLIDES

E.R. Plante and J.W. Hastie

U.S. DEPARTMENT OF COMMERCE

National Bureau of Standards

Institute for Materials Science and Engineering

High Temperature Chemistry

Ceramics Division

Gaithersburg, MD 20899

January 1986

Interim Report

U.S. DEPARTMENT OF COMMERCE, Malcolm Baldrige, Secretary NATIONAL BUREAU OF STANDARDS, Ernost Ambler, Director 

ABSTRACT.

1. Introduction.

2. Experimental Techniques

2.1 Knudsen Gravimetric Analysis

2.2 Knudsen Mass Spectrometry.

2.3 Transpiration Mass Spectrometry. . . . . . . . . . 5

3. Vaporization Studies of Selected Sub-Systems of Nuclear waste 6

3.1 Cesium Formate . . . . . . . . . . . . . 6

3.2 Cesium Hydroxide . . . . . . . . . . . . . . 9 9

3.3 Cesium Oxide.................... . . . 11

3.4 Cesium Carbonate . . . . . . . . . . . . . 16

3.5 Cesium Carbonate-Water Vapor . . . . . . . . . . 17

3.5 Sludge . . . . . . . . . . . . . . . . . 19

3.6.1 KMS Observations. . . . . . . . . . . . . 19

3.6 .2 TMS Observations. . . . . . . . . . . . 21

3.7 Sludge-Glass Erit Mixture. . . . . . . . . . . . . 22

3.7.1 KMS Observations. . . . . . . . . . . . 23

3.7.2 Knudsen Gravimetric Analysis. . . . . . . . . . 25

3.7.3 TMS Observations. . . . . . . . . . . 25

4. Conclusions . . . . . . . . . . . . . . . . . 26

5. Acknowledgements. . . . . . . . . . . . . . . . . . . 29

6. References. . . . . . . . . . . . . . . . . . 30

7. Eigure Captions . . . . . . . . . . . . . . . 32

8. Figures . . . . . . . . . . . . . . . . . 33

an the interests of accuracy and clarity in describing various items of equipment or apparatus, mention has been made of commercial sources or brand names. This in no way implies endorsement of such procucts by the

U.S. Government. 

Vaporization and Phase Equilibria of Simulated Radionuclides

E.R. Plante and J.W. Hastie

Institute for Materials Science and Engineering

National Bureau of Standards

Gaithersburg, MD 20899

\section{ABST RACT}

Undesirable losses of radionuclides occur by vaporization during processing of nuclear waste glass. This study examines the phase and chemical transformations that occur during the initial steps of waste incorporation into a borosilicate glass host. Specialized mass spectrometric and thermogravimetric techniques were used to monitor the vapor transport species over a range of temperature and composition. Significant vapor transport of CS was found and its enhancement by the presence of carbon, halogen, and water vapor was also noted.

Key words: Cesium, mass spectrometry, nuclear waste, thermodynamics, vaporization, $\mathrm{CsOH}, \mathrm{Cs}_{2} \mathrm{O}, \mathrm{Cs}_{2} \mathrm{CO}_{3}, \mathrm{CsO}_{2} \mathrm{CH}$.

\section{Introduction}

Industrial plans for nuclear waste storage call for the waste to be incorporated in borosilicate glass. A large fraction of the nuclear waste, known as "sludge", consists of both insoluble and hydrous oxides which have been reduced by formic acid. This siudge contains about $95 \%$ of the nuclear waste which, according to present plans, will be disposed of by vitrification in borosilicate glass at temperatures of $850-1150^{\circ} \mathrm{C}$ [Bickford, 1985]. Typical sludge and melter feed sludge-glass compositions are given in table 1. Plant experience suggests that losses of radionuclides, and particularly cesium, 
Table 1

Chemical Compositions of Sludge and Melter Feed Simulations

[Jantzen et al. 1982]

\begin{tabular}{|c|c|c|c|c|c|}
\hline Chemical & $\begin{array}{l}\text { Sludge } \\
(\text { wt } \% \text { ) }\end{array}$ & $\begin{array}{l}\text { Melter feed } \\
\quad(w t: \%)\end{array}$ & Chemical & $\begin{array}{l}\text { Sludge } \\
(\text { wt \%) }\end{array}$ & $\begin{array}{l}\text { Melter feed } \\
\qquad(w t ;)\end{array}$ \\
\hline \multirow{5}{*}{\multicolumn{2}{|c|}{$\begin{array}{l}\mathrm{SiO}_{2} \\
\mathrm{~B}_{2} \mathrm{O}_{3} \\
\mathrm{Na}_{2} \mathrm{O} \\
\mathrm{Li}_{2} \mathrm{O} \\
\mathrm{MgO}\end{array}$}} & 42.648 & $\mathrm{La}_{2} \mathrm{O}_{3}$ & 0.487 & 0.182 \\
\hline & & 6.272 & $\mathrm{ZrO}_{2}$ & 0.446 & 0.166 \\
\hline & & 8.153 & $\mathrm{CrCI}_{3} \cdot 6 \mathrm{H}_{2} \mathrm{O}$ & 1.095 & 0.408 \\
\hline & & 4.390 & $\mathrm{Ag}$ & 0.078 & 0.029 \\
\hline & & 0.627 & $\mathrm{Cu}_{2} \mathrm{O}$ & 0.083 & 0.031 \\
\hline \multicolumn{2}{|l|}{$\mathrm{ZrO}_{2}$} & 0.627 & $\mathrm{CoCl}_{2} \cdot 6 \mathrm{H}_{2} \mathrm{O}$ & 0.012 & 0.004 \\
\hline $\mathrm{Fe}_{2} \mathrm{O}_{3}$ & 24.769 & 9.234 & $\mathrm{Zn}$ & 0.165 & 0.062 \\
\hline $\mathrm{Mn}(\mathrm{COOH})_{2}$ & 12.321 & 4.594 & $\mathrm{Mg}\left(\mathrm{NO}_{3}\right) \cdot 6 \mathrm{H}_{2} \mathrm{O}$ & 1.792 & 0.668 \\
\hline \multirow{2}{*}{$\begin{array}{l}\mathrm{UO}_{2}\left(\mathrm{NO}_{3}\right)_{2}^{2} \cdot 6 \mathrm{H}_{2} \mathrm{O} \\
\mathrm{Al}(\mathrm{OH})_{3}\end{array}$} & 9.040 & 3.370 & $\mathrm{Na}_{3} \mathrm{PO}_{4} \cdot 12 \mathrm{H}_{2} \mathrm{O}$ & & 0.020 \\
\hline & 15.567 & 5.804 & $\mathrm{NaF}$ & & 0.030 \\
\hline $\mathrm{CaCO}_{3}$ & 3.437 & 1.281 & $\mathrm{Cs}_{2} \mathrm{O}$ & & 0.028 \\
\hline $\mathrm{CaSO}_{4}^{3}$ & 0.171 & 0.064 & Coal & 0.063 & 0.023 \\
\hline $\mathrm{PO}_{4}$ & 0.094 & 0.035 & Zeolite & 5.654 & 2.108 \\
\hline $\begin{array}{l}\mathrm{CaF}_{2} \\
\mathrm{NiO}^{2}\end{array}$ & $\begin{array}{l}0.080 \\
2.004\end{array}$ & $\begin{array}{l}0.030 \\
0.747\end{array}$ & $\begin{array}{l}\mathrm{Na}_{2} \mathrm{SO}_{4} \\
\mathrm{KOH}\end{array}$ & $\begin{array}{l}0.148 \\
0.249\end{array}$ & 0.055 \\
\hline $\mathrm{NaCl}$ & 0.273 & 0.102 & $\mathrm{Sr}\left(\mathrm{NO}_{2}\right)_{2}$ & 0.174 & 0.065 \\
\hline $\mathrm{HgO}$ & $1.804^{2}$ & $0.673^{a}$ & $\mathrm{HCOOH}(90 \%)$ & $11.5^{\mathrm{c}}$ & $4.03^{\circ}$ \\
\hline $\mathrm{NaI}$ & 0.008 & 0.003 & & & \\
\hline \multirow{2}{*}{$\begin{array}{l}\mathrm{RuO}_{2} \\
\mathrm{Na}_{2} \mathrm{SiO}_{3} \cdot 9 \mathrm{H}_{2} \mathrm{O}\end{array}$} & 0.241 & 0.090 & $\mathrm{SiO}_{2}$ & $0.464^{d}$ & $0.883^{d}$ \\
\hline & 18.063 & 6.735 & $\mathrm{Al}_{2} \mathrm{O}_{3}$ & $0.108^{d}$ & $0.040^{d}$ \\
\hline \multirow{2}{*}{$\mathrm{ThO}_{2}$} & 0.637 & 0.237 & $\mathrm{~B}_{2} \mathrm{O}_{3}$ & $0.000^{d}$ & $0.090 d$ \\
\hline & 0.227 & 0.085 & AIkali & $0.011^{d}$ & $0.560^{d}$ \\
\hline \multirow{2}{*}{$\begin{array}{l}\mathrm{Ce}\left(\mathrm{SO}_{4}\right)_{2} \\
\mathrm{PbSO}_{4}\end{array}$} & 0.636 & 0.237 & Alkali earths & $0.052^{d}$ & $0.035^{d}$ \\
\hline & 0.345 & 0.129 & $\mathrm{Ee}$ & $0.234^{d}$ & $0.087^{d}$ \\
\hline \multirow{2}{*}{\multicolumn{2}{|c|}{$\begin{array}{l}a_{N o t} \text { added to simulation } \\
b_{\text {Linde }} A W 500\end{array}$}} & & $\begin{array}{l}\text { met inansition } \\
\text { metals }\end{array}$ & 0.2340 & $0.087^{d}$ \\
\hline & & & Rare earths & $0.030^{\circ}$ & $0.001^{d}$ \\
\hline \multicolumn{2}{|c|}{$\begin{array}{l}\text { CComposition expressed as } \\
d^{C} \text { Composition expressed as }\end{array}$} & $\begin{array}{l}\mathrm{cm}^{3} / 100 \mathrm{~g} \\
\mathrm{~mol} / 100 \mathrm{~g}\end{array}$ & U, Th & $0.020^{d}$ & 0.008 \\
\hline
\end{tabular}


occur by vaporization. In a previous study [Hastie et al., 1983], we characterized these losses from simulated (non-radioactive) melter feed compositions. The present study focuses on the earlier processing stage of sludge heating and mixing with the glass host.

Because of the highly complex chemical and phase characteristics of sludge, it was necessary, in the present study, to examine key sludge components as well as the sludge itself. The component data provide the characteristic mass spectral ionization patterns and cross sections necessary to the analysis of complex mixtures. Also, the literature thermodynamic function and vapor pressure data for the reference state components is largely incomplete or inaccurate. These data are essential to the interpretation of experimental data and to the development of thermodynamic mixing models for complex mixtures such as the melter feed and sludge systems considered here. Emphasis has been given to determination of the vaporization characteristics of key cesium-containing compounds (non-active isotopes) and the vaporization behavior of synthetic sludge and sludge incorporated in the borosilicate glass.

Note in table 1, that the chemical composition of the typical melter-feed simulation (ie, non-radioactive isotopes) differs from that of our previous study [Hastie et al., 1983]. The major oxide components differ typically by a few wt $\%$ in each case. Also, the present composition contains salts such as sulfates, nitrates, and halides. These sulfate and nitrate forms should react at relatively low temperatures to form oxides which are then incorporated into the giass. However, the haIides may be more difficult to incorporate. 


\section{Experimental Techniques}

2.1 Knudsen Gravimetric Analysis (KGA)

With this classical technique, vaporizing species effuse from a container-cell through a small orifice ( $1 \mathrm{~mm}$ diameter) into a high vacuum. The equation

$$
P=\left(\frac{m}{C A t}\right)\left(\frac{2 \pi R T}{M}\right)^{1 / 2}
$$

relates the vapor pressure (P) to the rate at which mass ( $\mathrm{m}$ ) is transferred through an orifice (area A); where $t$ is time, $R$ the universal gas constant, $T$ the absolute temperature, and $M$ the molecular weight of the effusing species. The factor $C$ corrects for the transmission of the vapor through a non-ideal orifice (i.e., not infinitely thin). This relationship is based on the condition of molecular effusion where the molecular mean free path is larger than the orifice diameter. Cenerally, this places an upper pressure limit on the validity of the method at about $10^{-4}$ atm. This approach can be used to determine precise pressures but if more than a single vapor species is produced, and these are unrelated by a chemical constraint, then additional information is needed to partition the vapor species between the two or more competing reactions.

For the present study, a Mettler thermogravimetric analyzer was used.

\subsection{Knudsen Mass Spectrometry (KMS)}

This method combines the classical Knudsen technique, described above, with a mass spectrometric detector. The molecular beam emitted from the cell is passed through a rotating disk which modulates the beam. This procedure 
allows for phase sensitive detection which distinguishes beam gases from background. The technique is especially useful for permanent gases which otherwise would lead to untenable signal/noise ratios. Ion currents, produced by electron impact ionization, are converted to pressure using the expression

$$
P=k I_{i} T \text {, }
$$

where the partial pressure of species i is related to the observed ion signal, $I_{i}$, at temperature $T$, by a system constant, $k$, which contains ionization cross section, mass filter transmission, and geometric factors. This constant is usually determined by methods which depend on ion current data, integrated with respect to time and temperature, together with gravimetric data, as discussed in detail elsewhere [Hastie et al., 1983]. For the sludge-containing systems, the vapor composition was very complex and conversion of mass spectral ion intensities to partial pressures was accomplished using a constant average value of $k$ for all species. Errors of up to a factor of two may arise with this anproximation.

With the gas-inlet KMS system, the Knudsen cell is modified to allow the introduction of small quantities of gas into the cell. Hence, it is possible to study the interaction of the added gas with the condensed phase material in the cell.

\subsection{Transpiration Mass Spectrometry (TMS)}

The TMS technique uses a platinum transpiration cell, typically operating in the 0.1-1 atm total pressure range. A small orifice $(0.08 \mathrm{~mm}$ diameter), at the downstream end of the cell, serves as a sonic nozzle which produces a "frozen equilibrium" molecular beam. This beam is then directed toward a quadrupole mass spectrometer system in a specially designed high pumping 
speed vacuum system, as described earlier [Hastie, et al.,. 1983]. The differentially pumped molecular beam is modulated to isolate molecular beam components from scattered gas.

An advantage of the high pressure inlet system of TMS is that it decreases bubbling phenomena which can be a problem with the KMS method. Another advantage is that the much higher pressures present, and the relatively small orifice, lead to an increased residence time (seconds versus milliseconds for the KMS system) and hence a closer approach to thermodynamic equilibrium. The TMS technique is also the only method which provides mass analysis of vaporization products above the pressure range allowed in Knudsen effusion measurements. It should be recognized, however, that because of the Iow beam temperature, the characteristic electron impact mass spectrum can differ significantly from that found in KMS measurements [Bonnell and Hastie, 1979]. For certain alkali salts this leads to difficulty in detecting parent molecular ions.

Vapor pressures can be related to ion currents using the known carrier gas pressure as a reference. Alternatively, ion current integrations can be used, in combination with measured mass losses, to determine the instrument sensitivity, as discussed earlier [Hastie et al., 1983].

3. Vaporization Studies of Selected Sub-Systems of Nuclear Waste

\subsection{Cesium formate}

Meisel et al. [1975] have studied the decomposition of alkali retal (M) formates using thermogravimetric analysis (TGA). The results indicate the reactions: 


$$
\begin{aligned}
& 2 \mathrm{MO}_{2} \mathrm{CH}(\mathrm{s}, l)=\mathrm{M}_{2} \mathrm{C}_{2} \mathrm{O}_{4}(\mathrm{~s}, l)+\mathrm{H}_{2}(\mathrm{~g}) \\
& \mathrm{M}_{2} \mathrm{C}_{2} \mathrm{O}_{4}(\mathrm{~s}, l)=\mathrm{M}_{2} \mathrm{CO}_{3}(\mathrm{~s}, l)+\mathrm{CO}(\mathrm{g})
\end{aligned}
$$

and these may proceed stepwise or simultaneously. In addition, the direct observation of a small amount of carbon in the reaction product suggests that another reaction:

$$
2 \mathrm{CO}(\mathrm{g})=\mathrm{CO}_{2}(\mathrm{~g})+\mathrm{C}(\mathrm{s})
$$

takes place catalytically during the oxalate decomposition step (3.2). Meisel et al. [1975] found evidence for the oxalate intermediate step for sodium and potassium formate but rot cesium which proceeded directly to the carbonate and was independent of heating rate, atmosphere or container material (glass or platinum). However, our TGA experiments in vacuum indicated that the two reactions can be separated if the temperature is changed stepwise. At $210^{\circ} \mathrm{C}$, reaction (3.1) proceeded to completion, although at a slow rate (time scale - 2 hrs). On raising the temperature to $325^{\circ} \mathrm{C}$ no further weight loss occurred. At $425^{\circ} \mathrm{C}$, reaction (3.2) commenced and was driven to completion at $475^{\circ} \mathrm{C}$

Both the KMS and TMS mass spectrometer results clearly confirmed reaction (3.1), with the observation of $\mathrm{H}_{2}$ but not $\mathrm{CO}$ (or $\mathrm{CO}_{2}$ ) at Iow temperatures. It is noteworthy that $\mathrm{Cs}^{+}$was present in the mass spectrum during this stage and the signal disappeared as the $\mathrm{H}_{2}$ emission fell at the end of reaction ( 3.1 ). This could be due to an here-to-fore undocumented vaporization of $\mathrm{CsO}_{2} \mathrm{CH}$ as a stable vapor species. Alternatively, at this low a temperature $\left(190^{\circ} \mathrm{C}\right)$, both $\mathrm{Cs}(\ell)$ and, to a much lesser degree, CsOH( 2$)$ are sufficiently volatile to be transported and either might be formed by reaction with $\mathrm{H}_{2}$. In fact, both the $\mathrm{Cs}$ and $\mathrm{H}_{2}$ mass spectrometric signais decreased with time together, which indicates that Cs is most likely a reaction product of $\mathrm{H}_{2}$ with the sample. The IGA results also indicated the 
same coupled loss of $\mathrm{Cs}$ and $\mathrm{H}_{2}$ but at $228^{\circ} \mathrm{C}$. The higher temperature required in this case was due to the lower sensitivity of the TGA method, relative to KMS or TMS. Analysis of the TGA Knudsen effusion data indicated that about one percent of the initial Cs content of the sample was lost to the vapor phase during $\mathrm{H}_{2}$ release. No further weight loss was observed on raising the temperature through $325^{\circ} \mathrm{C}$.

During the second step (3.2) CO emission was evident, and the final residue was predominately $\mathrm{Cs}_{2} \mathrm{CO}_{3}(\mathrm{c})$. TGA analysis indicated that reaction (3.2) began at $425^{\circ} \mathrm{C}$ and was driven to completion by $475^{\circ} \mathrm{C}$. The product contained a small amount of elemental carbon which is a strong $\mathrm{O}_{2}$ scavenger. With the $\mathrm{O}_{2}$ partial pressure lower by several orders of magnitude (below the - $10^{-8}$ atm detection limit of KMS), the environment is reducing and the resulting partial pressure of $\mathrm{Cs}$ over formate-derived $\mathrm{Cs}_{2} \mathrm{CO}_{3}$ is roughly an order of magnitude greater than that observed from reagent-grade $\mathrm{Cs}_{2} \mathrm{CO}_{3}$, as discussed below (section 3.4 ).

TMS measurements carried out at a total pressure of $0.3 \mathrm{~atm}\left(\mathrm{~N}_{2}\right.$ carrier gas) also showed the loss of $\mathrm{Cs}$ associated with $\mathrm{H}_{2}$ evolution. With more sample than was used in the Knudsen effusion experiments, and with higher heating rates, evolution of $\mathrm{H}_{2}, \mathrm{CO}$, and $\mathrm{Cs}$ was observed at a total carrier gas pressure of 1 atm and at temperatures near $500^{\circ} \mathrm{C}$ before exhaustion of $\mathrm{H}_{2}$. At temperatures in the $500-700^{\circ} \mathrm{C}$ region, appreciable pressures of $\mathrm{CO}$ and $\mathrm{Cs}$, as well as a significant $\mathrm{CO}_{2}$ signal, were observed. The high Cs signals most likely resulted from reduction of the formate-derived cs by the C(s) formed during the decomposition process. Further discussion of this process is given below in section 3.4 . 
The JANAF thermochemical tables [JANAF, 1971] provide derived heat of formation data for $\mathrm{CsOH}$ which should be considered an approximation. This derivation is based on: atomic absorption spectroscopic observation of Cs-depletion in flames, electron impact mass spectrometric data, and bond energy analogy with other alkali hydroxides. Besides the monomer, the dimer $(\mathrm{CsOH})_{2}$ has also been observed by mass spectrometry. A derivation of the dimer heat of formation was made by JANAF [1971] using the equilibrium data of Schoonmaker and Porter [1959] for the interaction of $\mathrm{KOH}$ and CsOH to form the respective dimers. From these results, the difference in the heat of dimerization of $\mathrm{KOH}$ and $\mathrm{CsOH}$ was obtained. The heat of formation of the dimer is thus based on that for $(\mathrm{KOH})_{2}$ and this measured difference. It should be noted that the $(\mathrm{KOH})_{2}$ heat of formation given by JANAF [1971, 1975] has been revised recently, as discussed elsewhere [Hastie, et al. 1984] and the JANAF $(\mathrm{CsOH})_{2}$ data should therefore be revised.

Accurate vapor pressure measurements of $\mathrm{CsOH}$ are difficult to make because of interaction with the cell material, its tendency to creep from the cell and vaporize from external surfaces, and the possibility of reaction with $\mathrm{CO}_{2}$ after preparation and handling such that the activity of $\mathrm{CsOH}(l)$ is reduced.

In the present study, vapor pressure data were obtained using both the TGA and KMS techniques. The pressures obtained from the TGA Knudsen effusion experiment, as given in figure 1, were calculated assuming that $\mathrm{CsOH}(g)$ was the only vapor species. Based on the KMS results, and related discussion given below, the true molecular weight lies between that of $\mathrm{CsOH}$ and (CsOH) 2 . The pressure scale of the figure 1 TCA data is probably about 10 percent too 
high, which is similar to the experimental uncertainty. A second law analysis of the data gives a heat of vaporization at $298 \mathrm{~K}$ of $27.8 \mathrm{kcal} / \mathrm{mol}$ while the third law value is $32.6 \mathrm{kcal} / \mathrm{mol}$. The JANAF [1971] value is $35.0 \mathrm{kcal} / \mathrm{mol}$.

KMS experiments using the $\mathrm{CSOH}$ sample from the TGA experiment indicated $\mathrm{Cs}^{+}, \mathrm{CsOH}^{+}$and $\mathrm{Cs}_{2} \mathrm{OH}^{+}$mass spectral ions. At a nominal $30 \mathrm{eV}$ ionizing electron energy, the following relative ion intensities were found: $\mathrm{Cs}^{+}(100)$, $\mathrm{CsOH}^{+}(14)$, and $\mathrm{Cs}_{2} \mathrm{OH}^{+}(10)$. Thus the dimer is present at approximately 10 percent of the monomer partial pressure, in marked contrast to the literature value as evaluated by JANAF [1971], eg. see figure 1. This difference could be due, in part, to the following observation. Increasing the temperature after depletion of the $\mathrm{CsOH}$ from the Knudsen cell showed that the sample contained $\mathrm{Cs}_{2} \mathrm{CO}_{3}$ as indicated by the appearance of $\mathrm{CO}_{2}{ }^{+}$and $\mathrm{O}_{2}{ }^{+}$. The presence of a dissolved impurity, such as carbonate, would decrease the $\mathrm{CsOH}$ thermodynamic activity. Since the $\mathrm{CsOH}$ pressure is proportional to the activity, while the dimer pressure is proportional to its square, impurities will have a greater effect on the dimer pressure. However, the original sampie would have to contain at least 70 percent dissolved $\mathrm{Cs}_{2} \mathrm{CO}_{3}$ to account for the difference between our KMS data and JANAF's. Such an impurity level, and degree of carbonate solubility, is highly unlikely. Also, the high pressure found by KGA (in fig. 1) suggests a CsOH activity near unity. Thus we conclude that the true dimer concentration falls closer to the 10 percent value observed in this work than to the literature value of 80 percent (JANAF, 1971). Based on the present mass spectrometric observations, the dimer concentration is estimated to be $25 \pm 10$ percent which would indicate an average molecular weight for the KGA measurements (fig. 1) of 187 rather than the assumed $150 \mathrm{amu}$. This dimer concentration is consistent with the trends observed for the other alkali hydroxide systems, eg. see Hastie et. al [1984]. 
Although there is considerable uncertainty with respect to the relative importance of the monomer and dimer, both in this and the earlier literature work, it is clear that the high volatility of the hydroxide may lead to significant transport of $\mathrm{CS}$ in the presence of a high $\mathrm{H}_{2} \mathrm{O}$ partial pressure in the glass-sludge reactor atmosphere. Future measurements should be made over solid $\mathrm{CsOH}$, using higher sensitivity mass spectrometry, to avoid the liquid creep and reaction problems encountered.

\subsection{Cesium Oxide}

Lamoreaux and Hildenbrand [1984] and GIushko et al. [1978-1982] have recently reviewed the literature and recommended thermodynamic functions for the more thermally stable cesium oxide compounds, as summarized in table 2. The agreement between the tivo data sets is reasonably good except for $\mathrm{Cs}_{2} \mathrm{O}_{2}(\mathrm{c})$. Lamoreaux and Hildenbrand [1984] used reaction enthalpy data from Berardinelli and Kraus [1974] for

$$
2 \mathrm{CsO}_{2}(\mathrm{~s})=\mathrm{Cs}_{2} \mathrm{O}_{2}(\mathrm{~s})+\mathrm{O}_{2}(\mathrm{~g})
$$

together with the heat of formation of $\mathrm{CsO}_{2}(\mathrm{~s})$. Glushko et al. [1978-1982] used data from Centnerziver and Blumenthal [1933] based on the reaction,

$$
2 \mathrm{Cs}_{2} \mathrm{O}_{2}(l)=2 \mathrm{Cs}_{2} \mathrm{O}(2)+\mathrm{O}_{2}(\mathrm{~g})
$$

together with the heat of formation of $\mathrm{Cs}_{2} \mathrm{O}(2)$. However, the data of Centnerzier and 31 umenthal [1933] is probably not reliable because it was taken at temperatures where only a single liquid phase exists, contrary to reaction (3.5). Hence the value given by Lamoreaux and Hildenbrand [1984] is preferred. 
Table 2

Heats of Formation and Entropies of Cs-O Compounds at $298 \mathrm{~K}$

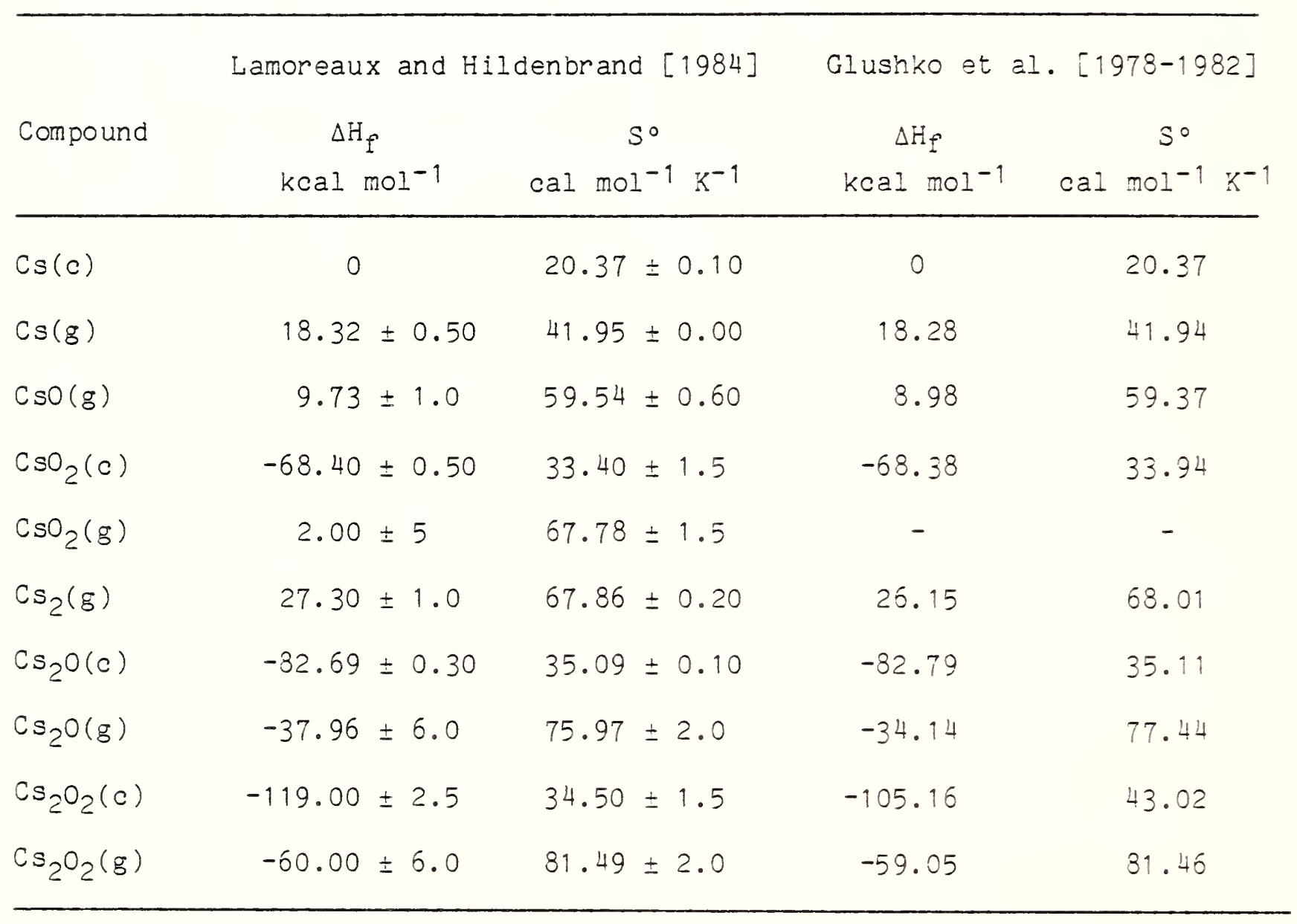


The derived heats of formation for $\mathrm{Cs}_{2} \mathrm{O}_{2}(\mathrm{~g})$ and $\mathrm{Cs}_{2} \mathrm{O}(\mathrm{g})$ are based on two separate mass spectrometric vaporization studies by Gusarov et al. [1967a] and Norman and Staley [1966]. Gusarov et al. [1967a] used $\mathrm{CsO}_{2}(\mathrm{~s})$ as a starting material which was then thermally decomposed in the Knudsen cell to form $\mathrm{Cs}_{2} \mathrm{O}_{2}(\mathrm{~s})$. Following this thermal decomposition step and the evaporation of $\mathrm{CsOH}$ impurity, mass spectral ion intensity data ( ${ }^{+}$) were obtained for $\mathrm{O}_{2}^{+}, \mathrm{Cs}^{+}, \mathrm{Cs}_{2} \mathrm{O}^{+}$, and $\mathrm{Cs}_{2} \mathrm{O}_{2}{ }^{+}$. Their plots of $10 \mathrm{~g} \mathrm{I}^{+} \mathrm{T}$ vs $1 / \mathrm{T}$ yielded straight lines, as required to a first approximation by the second law of thermodynamics. However, the slopes apparently did not correspond to meaningful enthalpies of sublimation or vaporization because of sample interaction with the platinum effusion cell. These data were therefore used to calculate heats for the all-gas reactions

$$
\begin{aligned}
& \mathrm{Cs}_{2} \mathrm{O}(\mathrm{g})=2 \mathrm{Cs}(\mathrm{g})+1 / 2 \mathrm{O}_{2}(\mathrm{~g}) \\
& \mathrm{Cs}_{2} \mathrm{O}_{2}(\mathrm{~g})=2 \mathrm{Cs}(\mathrm{g})+\mathrm{O}_{2}(\mathrm{~g})
\end{aligned}
$$

which, in principal, are independent of the composition of the condensed phase. Other data given by Gusarov et al. [1967a] indicate oxygen pressures at about ten times higher than those required to maintain $\mathrm{Cs}_{2} \mathrm{O}_{2}$ (s) at the stoichiometric composition. In addition, the mass spectral ion with the highest intensity was $\mathrm{CS}^{+}$which was formed by ionization of $\mathrm{Cs}(\mathrm{g})$. Also, plots of the ion ratios $\mathrm{Cs}^{+} / \mathrm{O}_{2}^{+}$and $\mathrm{Cs}^{+} / \mathrm{CsO}_{2}{ }^{+}$as a function of vaporization time, shown in figure 2 , indicate a shift in composition towards a more Cs-rich sample.

The second mass spectrometric study, by Norman and Staley [1966], provides additional data on the heat of formation of $\mathrm{Cs}_{2} \mathrm{O}(\mathrm{g})$ and $\mathrm{Cs}_{2} \mathrm{O}_{2}(\mathrm{~g})$. However, those authors did not detect a significant $\mathrm{Cs}^{\dagger}$ signal over $\mathrm{Cs}_{2} \mathrm{O}(\mathrm{c})$, in contrast to the measurements of Gusarov et al. [1967a]. This observation indicates considerable uncertainty concerning the composition of the 
condensed phase in most of these measurements. Norman and Staley's measurements were made by passing $\mathrm{O}_{2}$ through a reentrant tube into the Knudsen cell to establish a relatively high $\mathrm{O}_{2}$ pressure (perhaps $10^{-4}$ atm). They monitored reaction (3.6) in addition to

$$
\mathrm{Cs}_{2} \mathrm{O}_{2}(\mathrm{~g})=\mathrm{Cs}_{2} \mathrm{O}(\mathrm{g})+1 / 2 \mathrm{O}_{2}(\mathrm{~g}) \text {. }
$$

For reaction $(3.8)$, the sample composition was believed to be between $\mathrm{Cs}_{2} \mathrm{O}_{2}(\mathrm{c})$ and $\mathrm{Cs}_{2} \mathrm{O}(\mathrm{c})$ but not very close to either, while for reaction $(3.6)$ : cesium silicate was used as the source ố Cs. The third law data obtained are similar to the values recommended by Lamoreaux and Hildenbrand [1984].

In this study, KMS vaporization experiments were conducted on $\mathrm{Cs}_{2} \mathrm{O}(\mathrm{c})$ using a sample obtained from Alfa in the as-received condition. The sample consisted of large purplish-greenish chunks and, to minimize reaction with the ambient atmos-phere, a single chunk was inserted into a platinum Knudsen cell and loaded into the mass spectrometer as rapidly as possible. Even with these pre-cautions mass spectral ions (at $\mathrm{m} / \mathrm{e}$ of 133,150 , and 283 amu), corresponding to the presence of condensed $\mathrm{CsOH}(\mathrm{c})$, were identified during the initial heating period. The disappearance of the 150 and 283 amu ion signals with time indicated that $\mathrm{CsOH}$ had been purged from the sample. In the initial heating stage the $\mathrm{O}_{2}{ }^{+} / \mathrm{Cs}^{+}$ratio was unusually high, indicating that the original $\mathrm{Cs}_{2} \mathrm{O}(\mathrm{c})$ sample contained $\mathrm{O}_{2}$ in excess of the stoichiometric amount.

Following this initial heating period, data were obtained for $\mathrm{Cs}^{+}, \mathrm{O}_{2}^{+}$, and $\mathrm{Cs}_{2} \mathrm{O}^{+}$. From the $\mathrm{log} \mathrm{I}^{+} \mathrm{T}$ vs $1 / \mathrm{T}$ results, the $\Delta \mathrm{H}(\mathrm{T})$ values for $\mathrm{Cs}, \mathrm{O}_{2}$ and $\mathrm{Cs}_{2} \mathrm{O}$ were $39.1,39.0$, and $49.5 \mathrm{kcal} \mathrm{mol}^{-1}$, respectively. When treated as though reaction (3.6) took place, a second law heat of $53.7 \mathrm{kcal} \mathrm{mol}^{-1}$ was obtained. The equilibrium constant data for this reaction are given in figure 3, together with the recommended data of Lamoreaux and Hildenbrand 
[1984] for comparison. Using an estimated value of the mass spectrometer constant (k), a third law reaction enthalpy of $64.8 \mathrm{kcal} \mathrm{mol}^{-1}$ was cbtained. The third law value is fairly insensitive to the accuracy of the mass spectrometer constant and is likely to be more reliable than the second law value. From the third law reaction enthalpy, we obtain $\Delta H_{f}(298)$ Cs2O(g) equal to $-28.2 \mathrm{kcal} \mathrm{mol}^{-1}$. This value is about 10 and $6 \mathrm{kcal} \mathrm{mol}^{-1}$ less negative than the values recommended by Lamoreaux and Hildenorand [1984] and Giushko et al. [1978-1982], respectively. The close agreement betiven the vaporization enthalpies for $\mathrm{CS}^{+}$and $\mathrm{O}_{2}^{+}$and the relative ion intensities indicate that the parents of these ions ( $\mathrm{Cs}$ and $\mathrm{O}_{2}$ ) are most likely joth formed by thermal dissociation of $\mathrm{Cs}_{2} \mathrm{O}(\mathrm{g})$ (i.e. reaction 3.5).

Measurements of the vaporization enthalpy for $\mathrm{Cs}_{2} \mathrm{O}(\mathrm{c})$ have also been reported by Nicolosi, Tang, and Munkelwitz [1979]. They also used a phase-locked mass spectrometer system. Although $\mathrm{Cs}^{+}$was the most abundant ion they assumed it was formed as an electron imoact fragment of $\mathrm{Cs}_{2} \mathrm{O}(\mathrm{g})$. From a plot of $\log \mathrm{I}^{+} \mathrm{T}$ vs $1 / \mathrm{T}$ for $\mathrm{Cs}_{2} \mathrm{O}^{+}$they obtained a $\Delta \mathrm{H}_{\mathrm{V}}(-1000 \mathrm{~K})$ vaIue of $62.9 \mathrm{kcal} \mathrm{mol}^{-i}$. The expected value, based on Lamoreaux and Hildenbrands' [1984] analysis, is $35.7 \mathrm{kcal} \mathrm{mol}^{-1}$. Using a similar assumption for the source of $\mathrm{Cs}^{+}$, our data would yield $49.5 \mathrm{kcal} \mathrm{mol}{ }^{-1}$.

We also attempted to reproduce the results of Norman and Staley [1966] by passing $\mathrm{O}_{2}(\mathrm{~g})$ over the $\mathrm{Cs}_{2} \mathrm{O}(\mathrm{c})$ phase. This aporoach should have allowed us to determine an equilibrium constant for reaction (3.8). However, this was not possible as we were unable tc observe $\mathrm{Cs}_{2} \mathrm{O}_{2}+$. Evidence for $\mathrm{C}_{2}$ absorption was provided by an observed decrease in the $\mathrm{Cs}^{+}$and $\mathrm{Cs}_{2} \mathrm{O}^{+}$signals. Also, on increasing the sample temperature, there was an increase in the $\mathrm{O}_{2}{ }^{-} \mathrm{sinal}_{\mathrm{i}}$ This apparently means that the oxygen pressure over $\mathrm{Cs}_{2} \mathrm{O}_{1}+\mathrm{x}$ is scmewhere in the $10^{-4}$ atm range at $900 \mathrm{~K}$. 
Vaporization measurements were carried out using both the TGA and KMS systems. Samples included pure $\mathrm{Cs}_{2} \mathrm{CO}_{3}$ and $\mathrm{Cs}_{2} \mathrm{CO}_{3}$ derived from the thermal decomposition of $\mathrm{CsO}_{2} \mathrm{CH}$. As with other alkali metal carbonates, the most important vaporization process is

$$
\mathrm{Cs}_{2} \mathrm{CO}_{3}(\mathrm{~s}, l)=2 \mathrm{Cs}(\mathrm{g})+\mathrm{CO}_{2}(\mathrm{~g})+1 / 2 \mathrm{O}_{2}(\mathrm{~g}) \cdot(3.9)
$$

Gusarov et al. [1957b] have demonstrated that a negligibly small fraction of the saturated vapor consists of $\mathrm{Cs}_{2} \mathrm{CO}_{3}(\mathrm{~g})$ and $\mathrm{Cs}_{2} \mathrm{O}(\mathrm{g})$. These minor constituents were also observed in our KMS measurements but will not be of further interest here.

Data from the KGA Knudsen experiments, using both pure carbonate and formate-derived carbonate, are shown in figure 4. Accepting that the decomposition reaction (3.9) is dominant, one can show that the Cs pressure is 1.28 times the effective pressure calculated using the molecular weight of $\mathrm{Cs}_{2} \mathrm{CO}_{3}$. The calculated pressures for the formate-derived carbonate are 10 to 100 times greater than the pressures measured using the pure carbonate. This is caused by the carbon residue formed during the decomposition of the formate, as noted above in section 3.1. Note in figure 4 that the Cs pressures over pure carbonate agree within a factor of 3 with those calculated from the thermodynamic functions given by Glusiko et al [1978-1982] while the pressures for the formate-derived carbonate are in reasonable agreement with the pressures calculated for carbon-reduced carbonate.

In the KMS experiments on the formate-derived carbonate, the cominant ions were $\mathrm{CS}^{+}, \mathrm{CO}_{2}^{+}$and $\mathrm{CO}^{+}$. The $\mathrm{O}_{2}^{+}$signal was below the detection limit of the mass spectrometer and this may be contrasted with the pure carbonate case 
where $\mathrm{O}_{2}^{+}$was readily observable. This result' also confirms the reduction process of the formate-derived carbonate. Although the amount of carbon formed in the decomposition of the formate is believed to be small, $\mathrm{CO}^{+}$ signals were persistent throughout the sample vaporization. However, all signals decreased with time, showing that kinetic factors were causing a deviation from equilibrium which is typical of reactions involving two condensed phases.

The KMS CS pressure results obtained over pure $\mathrm{Cs}_{2} \mathrm{CO}_{3}$ are shown in figure 5. For these measurements the mass spectrometer calibration constant was determined from the measured weight loss and the mass spectrometric data expressed as $\left[I \cdot t \cdot T^{1 / 2}\right.$. The measured $C s$ pressure is roughly a factor of 10 greater than the Cs pressure calculated from the thermodynamic data tabulated by Glushko et al. [1978-1982]. A possible explanation for this difference is that a shift in sample composition takes place under the vacuum vaporization conditions. Reisman [1958] has reported that alkali carbonates, inciuding $\mathrm{Cs}_{2} \mathrm{CO}_{3}$, melt at lower temperatures in the absence of $\mathrm{CO}_{2}$ than they do in a $\mathrm{CO}_{2}$ atmosphere. This effect could be caused by partial decomposition to form an oxide-carbonate solution in the absence of a relatively high $\mathrm{CO}_{2}$ pressure.

\subsection{Cesium Carbonate - Water Vapor}

The relatively nigh partial pressure of $\mathrm{H}_{2} \mathrm{O}$ in the off-gas for the nuclear waste process leads to the possibility of water interaction with Cs salts dissolved in the borosilicate glass. In oun previous work [Hastie et al., 1983] with cs-containing borosilicate glass we were unable to observe any enhancement in CS transport in the presence of water vapor. This lack of reactivity was attributed to the low thermodynamic activity of cs ir the glass 
which was probably bound as $\mathrm{CsBO}_{2}$. On the other hand, Carpenter et al. [1983] did observe an $\mathrm{H}_{2} \mathrm{O}$ enhancement of $\mathrm{Cs}$ transport over Synroc $\left(\mathrm{Ba}_{0}, 9 \mathrm{CsO} .1 \mathrm{Al}_{2} \mathrm{Ti}_{6} \mathrm{O}_{16} \mathrm{TiO}_{2}\right)$, but in this case the $\mathrm{Cs}$ is undoubtedly present at a higher activity.

The conversion of $\mathrm{CsO}_{2} \mathrm{CH}$ to carbonate may provide a potential source for water reaction with formate-derived carbonate. Therefore measurements were made on the effect of $\mathrm{H}_{2} \mathrm{O}$ on $\mathrm{Cs}_{2} \mathrm{CO}_{3}$ evaporation using the gas-inlet KMS system. Observation of the 150 amu species, $\mathrm{CsOH}^{+}$, and an enhanced $\mathrm{CO}_{2}{ }^{+}$ signal indicated the reaction

$$
\mathrm{Cs}_{2} \mathrm{CO}_{3}(\mathrm{c})+\mathrm{H}_{2} \mathrm{O}(\mathrm{g})=2 \mathrm{CsOH}(\mathrm{g})+\mathrm{CO}_{2}(\mathrm{~g}) \cdot(3 \cdot 10)
$$

Data obtained for this process at $1010 \mathrm{~K}$ are plotted in figure 6 . The curve with zero slope shows that the reaction equilibrium constant, expressed as an ion intensity quotient, is independent of the ion intensity (and hence pressure) of $\mathrm{H}_{2} \mathrm{O}$. This result indicates establishment of equilibrium or, at the least, a steady state with respect to reaction $(3.10)$. The second curve has a slope of 0.97 which is in excellent agreement with the theoretical slope of 1.0 for reaction $(3.10)$.

Absolute equilibrium constant data were calculated from the results given in figure 6 using the mass spectrometer constant $(k)$. Figure 7 compares the experimental data with the curve calculated from the tabulation of Glushko et al. [1978-1982]. The experimental curve is about three orders of magnitude lower than the calculated curve but this is not unusual with Knudsen effusion gas-solid experiments where the reactant gas residence time is short (usually milliseconds). At least part of this difference can be attributed to the considerable uncertainty in the literature Gibbs energy data for the $\mathrm{CsOH}$ species (see section 3.2) used to generate the calculated curve of figure 7. These results snow that cesium vapor transport can be 
enhanced significantly by water vapor, in accordance with reaction (3.10). However, this enhancement may be negligible in practice if the Cs activity is reduced by reaction with the borosilicate glass.

\subsection{Sludge}

\subsubsection{KMS Observations}

Experiments were carried out with samples having the composition given in table 1. The samples were contained in a platinum Knudsen cell. Because of the high sensitivity of the KMS technique, decomposition products can generally be observed at lower temperatures than for the TMS method or for actual reactor plant conditions. However, to maintain pressures in the Knudsen cell within the applicable limits ( $\left.<<10^{-4} \mathrm{~atm}\right)$, a relatively low heating rate $\left(-1{ }^{\circ} \mathrm{C} / \mathrm{min}\right)$ was necessary.

Decomposition of formates in the sludge was observed at $190-200^{\circ} \mathrm{C}$. Prominent mass peaks occured at $2,18,28,30$, and 44 amu. The mass peaks at 2 and 28 amu are characteristic of formate decomposition. Mass 18 amu is clearly water vapor which originates as residual water or as salt hydrates. The 44 amu signal may be associated with the reaction of $\mathrm{CO}$ to form $\mathrm{CO}_{2}$ and $C(s)$, as well as from the decomposition of residual carbonates. The origin of mass 30 amu is somewhat uncertain. This peak was not observed in the cesium formate mass spectrum but, nevertheless it does appear to be very closely related to formate decomposition in the sludge. The possibility that this peak corresponds to the NO radical was considered but the temperature is too 
low for decomposition of nitrate salts. The most likely assignment, is to formaldehyde, which may arise as an impurity in the formic acid used in the reduction process.

At temperatures near $500^{\circ} \mathrm{C}$ alkali salts began to vaporize from the sludge, as evidenced by the appearance of $\mathrm{Na}^{+}, \mathrm{K}^{+}, \mathrm{NaCl}^{+}$, and $\mathrm{KCl}^{+}$. The mass spectral ion $\mathrm{Na}_{2} \mathrm{Cl}^{+}$, resulting from $(\mathrm{NaCl})_{2}$ was also observed. The presence of the dimer suggests that $\mathrm{NaCl}(g)$ is near its saturation pressure and the condensed salt activity is near unity. Near $800^{\circ} \mathrm{C}$, the $\mathrm{NaF}^{+}$ion was also observed. This species assignment could be distinguished from $\mathrm{LiCl}^{+}$(at the same amu) because of the absence of $\mathrm{Li}^{+}$in the mass spectrum. At the temperatures involved, all the alkali metal ions result from mass spectral fragmentation of parent halide molecules. It may be noted that the sludge composition, as prepared, contains no KCl suggesting that this salt is formed by exchange reactions with other halides, as we have noted in other studies [Hastie and Plante, 1981]. These condensed phase reactions have the form

$$
2 \mathrm{ACI}+\mathrm{B}_{2} \mathrm{O}=2 \mathrm{BCI}+\mathrm{A}_{2} \mathrm{O},
$$

where $A$ and $B$ are different alkali (or even alkaline-earth and transition) metals and the oxides may also be combined as silicates, borates, etc.

Also, near $500^{\circ} \mathrm{C}$ the sulfate salts began to decompose, as indicated by the appearance of $\mathrm{SO}_{2}^{+}, \mathrm{SO}^{+}$, and $\mathrm{S}^{+}$, which are characteristic of the $\mathrm{SO}_{2}$ mass spectrum. The sludge melted at about $625^{\circ} \mathrm{C}$ and the signals became erratic at higher temperatures due to nucleation of bubbles formed from gaseous products which migrated through the melt and burst at the surface. The major component of the bubbles appeared to be $\mathrm{SO}_{2}$. However, the intensities of other mass peaks were also affected because bulk melt components, with higher 
concentrations than at the quiescent surface, can be transported to the surface by bubbling. Near $1000^{\circ} \mathrm{C} \mathrm{Pb}^{+}$was observed indicating vaporization of $\mathrm{Pb}(\mathrm{g})$ from the sludge.

\subsubsection{TMS Observations}

TMS experiments were carried out using an argon carrier gas. Because of the less stringent pressure requirement for the TMS system, the heating rate was faster $\left(-10^{\circ} \mathrm{C} / \mathrm{min}\right)$ than for the KMS experiments. Typical species evolution data, obtained for a single heating cycle over the range $150-450^{\circ} \mathrm{C}$, are shown in figure 8. The observed signals indicate thermal decomposition of the formates and other relatively unstable sludge components. Note that the curves for $\mathrm{H}_{2} \mathrm{O}^{+}, \mathrm{CO}_{2}^{+}$, and $\mathrm{H}_{2} \mathrm{CO}^{+}$have maxima near $280^{\circ} \mathrm{C}$. These correspond to the major signals seen in the KMS experiments near $200^{\circ} \mathrm{C}$. The low temperature at which these gases are expelled suggests that they are not strongly bonded in the sludge substrate. $\mathrm{CO}_{2}$ and $\mathrm{H}_{2} \mathrm{O}$ could originate from decomposition of bicarbonates, relatively unstable carbonates such as $\mathrm{PbCO}_{3}$, and from salt hydrates. As with the KMS observations, we believe that the $\mathrm{H}_{2} \mathrm{CO}^{+}$signaI originates from a formaldehyde impurity.

The second group of peaks, with maxima near $380^{\circ} \mathrm{C}$, are formed from formate decomposition but the rate of heating was high enough to allow the formate-oxalate and oxalate-carbonate transformations to occur simultaneously. As with the formates, $\mathrm{CO}_{2}$ is due to the decomposition of co which is thermodynamically unstable with respect to $\mathrm{CO}_{2}$ and $\mathrm{C}(\mathrm{s})$ in this temperature range. A third $\mathrm{CO}_{2}$ intensity maximum near $425^{\circ} \mathrm{C}$, presumably results from the decomposition of a relatively stable carbonate. 
At higher temperatures (than shown in fig. 8) $\mathrm{Na}^{+}, \mathrm{SO}_{2}^{+}, \mathrm{SO}^{+}$, and $\mathrm{S}^{+}$ were observed and at the highest temperatures, following the decay of the $\mathrm{SO}_{2}{ }^{+}$signal, the $\mathrm{O}_{2}^{+}$mass spectral species was observed. The $\mathrm{Na}^{+}$signal, which was observed throughout the temperature range, undoubtedly results from mass spectral fragmentation of $\mathrm{NaCl}(\mathrm{g})$ at the lower temperatures and from decomposition of $\mathrm{Na}_{2} \mathrm{SiO}_{3}(\mathrm{~s})$ or $\mathrm{Na}_{2} \mathrm{SO}_{4}(\mathrm{~s})$ at the higher temperatures. Note that $\mathrm{K}^{+}$was not observable in the TMS experiments because of interference by the Ar carrier gas at the 40 amu position.

The $\mathrm{SO}_{2}$ pressure showed relatively little temperature dependence but was gradually depleted from the sample with time. For Ar pressures of $0.2-0.4 \mathrm{~atm}$, no apparent $\mathrm{SO}_{2}$ bubble formation occurred, in contrast to the KMS experiments. The $\mathrm{O}_{2}$ pressure showed a temperature dependence similar to that calculated for $\mathrm{Fe}_{2} \mathrm{O}_{3}-\mathrm{Fe}_{3} \mathrm{O}_{4}$ reduction, indicating further reduction of $\mathrm{Fe}_{2} \mathrm{O}_{3}$ in the sludge. However, for the off-gas conditions present in the industrial glass reactor, loss of oxygen by reduction of $\mathrm{Fe}_{2} \mathrm{O}_{3}$ probably would not take place.

\subsection{Sludge-Glass Frit Mixture}

The sludge-frit or melter-feed mixture, as prepared by SRL [Bickford, 1985], consisted of sludge and a borosilicate glass frit, mixed in the respective weight proportion of 1/1.682, which was fused and quenched. The overall composition of the sludge-frit mixture, as given in table 1 , is similar, although not identical, to the synthetic nuclear waste glass studied by us earlier [Hastie, et al., 1983]. Several sampies were studied and the melting and quenching performed during preparation of the mixture appears to have removed most of the relatively volatile material associated 
with the formate salts. It is also likely that some of the glass-forming salts, such as sulfates, may have undergone partial reaction during the mixture preparation.

\subsubsection{KMS Observations}

The vaporization behavior of the mixture was quite erratic throughout the temperature range covered of $500-1150^{\circ} \mathrm{C}$. It appears that the sludge-frit mixture consists of at least two phases, one containing salt and the other glass-forming components. Such a phase separation would contribute to the erratic vaporization behavior.

In the $550-700^{\circ} \mathrm{C}$ temperature range, Cs vapor transport was indicated by the appearance of $\mathrm{CS}^{+}$, as shown in figure 9. At such low temperatures, CSCI, $\mathrm{CsOH}$, or possibly $\mathrm{CsNO}_{3}$, are candidate vapor species. Unfortunately, because of the small $\mathrm{Cs}^{+}$intensity, it was not possible to detect parent ion signals, which can be expected to be weaker than for the $\mathrm{Cs}^{+}$fragment. The most probable volatile species is considered to be CsCl because of the likelihood of alkali exchange reactions (such as 3.11) taking place in the mixture. The simultaneous observation of $\mathrm{LiCl}^{+}, \mathrm{NaCl}^{+}, \mathrm{Na}^{+}$and $\mathrm{Cs}^{+}$, as shown in figure 9 , is indicative of the presence of such reactions. Near $650^{\circ} \mathrm{C}$, other alkali metal ions and halides, including $\mathrm{Na}_{2} \mathrm{Cl}^{+}, \mathrm{KCl}^{+}, \mathrm{K}^{+}$, and $\mathrm{Li}^{+}$, were observed in addition to $\mathrm{LiCl}^{+}, \mathrm{NaCl}^{+}$and $\mathrm{Na}^{+}$. During this stage $\mathrm{SO}_{2}^{+}$and its fragments $\mathrm{SO}^{+}$and $\mathrm{S}^{+}$were also noted.

The appearance of $\mathrm{Na}_{2} \mathrm{Cl}^{+}$indicates $(\mathrm{NaCl})_{2}$ as a vapor species which, in turn, is evidence of a reasonably high $\mathrm{NaCl}$ activity in the condensed phase. In fact, at $800^{\circ} \mathrm{C}$ the $\mathrm{NaCl}$ partial pressure, when compared with the pure salt value [JANAF, 1971], indicates an activity of $3 \times 10^{-3}$. This value is 
about three times the ideal-solution value for the composition given in table 1 which is further evidence of salt-oxide phase separation. Likewise, the CsCl activity is observed to be at least an order-of-magnitude greater than that expected for a homogeneous phase with the composition of table 1 . On the other hand, the observed LiCl activity, using the partial pressure data of figure 9 and the JANAF [1971] reference state data, is about

$2 \times 10^{-3}$. This is much less than expected from the total amount of Li present (see table 1) and indicates only a relatively small conversion of $\mathrm{Li}_{2} \mathrm{O}$ to LiCl. The absence of $(\mathrm{LiCl})_{2}$ in the vapor is also consistent with a low LiCl activity.

Above $800^{\circ} \mathrm{C}$, mass spectral ions corresponding to $\mathrm{LiBO}_{2}, \mathrm{NaBO}_{2}$, and $\mathrm{O}_{2}$ were observed, as shown in figure 10, in addition to the various alkali halide and sulfate-derived ions already noted. In this temperature region, $\mathrm{Cs}^{+}$was not observed even though the concentration of $\mathrm{CsBO}_{2}$ in the glass phase should be comparable to that of the synthetic nuclear waste glass studied by us previously. Thus, it might be inferred that the Cs component of the sludge-frit mixture was lost as the volatile chloride before incorporation into the glass phase.

This conclusion is also supported by the magnitude of the $\mathrm{CS}^{+}$(CSCI) signal in figure 9, which is sufficiently high to cause sample depletion at temperatures less than $800^{\circ} \mathrm{C}$. The magnitude of the $K^{+}$ion intensities in figure 10 are also consistent with $\mathrm{KCl}$ as the precursor, as formed by the halogen exchange process. At the highest temperatures, $\mathrm{KBO}_{2}$ is also a possible mass spectral precursor for $\mathrm{K}^{+}$. The negative curvature shown in the high temperature range of figure 10, corresponds to a decreasing partial pressure caused by decreased concentration of the various volatile components in the melt. 
3.7.2 Knudsen Gravimetric Analysis

A sample of the sludge-frit mixture was subjected to knudsen gravimetric analysis. These measurements are complimentary to the mass spectrometric analysis since, in principle, the rate of vaporization can be related to the partial pressure of each vapor species. Figure 11 shows the rate of vaporization data and a hypothetical partial pressure which would be valid if only a single species of mass 50 amu was present in the rapor phase. In the present case, the sludge-frit system is complicated by the presence of many significant vapor species. A more detailed analysis can be made by apportioning the total mass loss between the various vaoor species observed mass spectrometrically. When this is done, the average vapor molecular weight increases to about 63 amu and the pressure scale of figure 11 is reduced by 10 percent, which is a negligible correction for the present purpose.

\subsubsection{TMS Observations}

Observations of the sludge-frit mixture, using the TMS system, were carried out at temperatures up to $1400^{\circ} \mathrm{C}$ using argon carrier gas pressures in the range $0.2-0.4 \mathrm{~atm}$. Representative data are given in figure 12 . In contrast with the KMS experiments, the high ambient pressure allowed a more uniform release of $\mathrm{SO}_{2}$ from the melt and troubiesome bubble formation was avoided. However, the lower TMS sensitivity oreciuded observation of low intensity species such as $\mathrm{Cs}^{+}, \mathrm{NaCl}^{+}$, and $\mathrm{LiCl}^{+}$. 
The $\mathrm{Li}^{+}$and $\mathrm{Na}^{+}$intensities, shown in figure 12, are derived from several species including $\mathrm{LiBO}_{2}$ and $\mathrm{NaBO}_{2}$ as the dominant precursors at the higher temperatures. Near $1150{ }^{\circ} \mathrm{C}$, the parent ions $\mathrm{LiBO}_{2}^{+}$and $\mathrm{NaBO}_{2}^{+}$were also observed. The approximate partial pressures of $\mathrm{LiBO}_{2}$ and $\mathrm{NaBO}_{2}$, given in figure 12, agree reasonably well with our earlier results on a similar glass composition [Hastie et al., 1983], particularly at the higher temperatures. At lower temperatures, the pressure scale is probably a factor of three too high, as may be seen by comparison with figure 11.

Sulfur dioxide was evolved over most of the temperature range but its partial pressure decreased with increasing temperature due to surface depletion between 1050 and $1250^{\circ} \mathrm{C}$ before increasing again. The oxygen species was readily detected above $1050^{\circ} \mathrm{C}$ but at lower temperatures the presence of $\mathrm{S}^{+}$from $\mathrm{SO}_{2}$ at the same amu interfered with its measurement.

4. Conclusions

The results of the present study indicate a variety of modes by which Cs can be lost to the vapor phase during the nuclear waste glass-forming process. These processes are sumnarized in simplified form in table 3 .

At $190^{\circ} \mathrm{C}$, pure $\mathrm{CsO}_{2} \mathrm{CH}$ converts to the oxalate with vaporization loss of about 1 percent of the total Cs.

At $250^{\circ} \mathrm{C}$, under conditions where a pure $\mathrm{CsOH}$ condensed phase is present, significant vaporization occurs as $\mathrm{CsOH}$ and $(\mathrm{CsOH})_{2}$.

At $500^{\circ} \mathrm{C}$, with relatively high heating rates, transformation of cesium formate to the oxalate and oxalate to carbonate can occur simultaneously. Under these conditions, Cs vapor transport occurs and appears to be enhanced 
by the presence of $\mathrm{H}_{2}(\mathrm{~g})$ or $\mathrm{C}(\mathrm{s})$ produced during the formate-oxalate decomposition. This conclusion is borne out by the vapor pressure measurements on formate-derived carbonate where the data fall in the range expected for reduction of $\mathrm{Cs}_{2} \mathrm{CO}_{3}$ by $\mathrm{C}$, as calculated from thermochemical data.

At $550^{\circ} \mathrm{C}$, Cs vapor transport can occur, probably as CsCl(g), by a condensed phase halogen exchange process involving $\mathrm{NaCl}, \mathrm{CrCl}_{3}$, or $\mathrm{CoCl}_{2}$.

At $700^{\circ} \mathrm{C}$, another mechanism whereby the formate-derived carbonate is converted to volatile species occurs by reaction with water vapor to produce $\mathrm{CsOH}(\mathrm{g})$

At $800{ }^{\circ} \mathrm{C}$, for conditions where condensed $\mathrm{Cs}_{2} \mathrm{CO}_{3}$ is present, the Cs decomposition pressure is significant.

At $1000^{\circ} \mathrm{C}$, the results of an earlier study [Hastie, et ai., 1983] indicate $\mathrm{Cs}$ vapor transport in the form of $\mathrm{CsBO}_{2}(\mathrm{~g})$. However, in the presence of halides most of the $C s$ can be lost at lower temperatures, as indicated above. It appears, therefore, that the presence of halides is detrimental to the stable incorporation of cesium in the borosilicate glass.

The degree of cesium vapor transport and the relative significance of the various reactions will, in practice, depend on the temperature-time history of the vitrification process. Development of thermodynamic mixing models, based on the present experimental data, and a solution model [eg. see Hastie and Bonnell, 1985] is required to model the plant-scale process. 
Table 3

Summary of processes leading to Cs vapor transport

Material

Temperature ${ }^{\circ} \mathrm{C}$

Process

$\begin{array}{lll}\text { cesium formate } & 190 & \mathrm{CsO}_{2} \mathrm{CH}(\mathrm{s}) \longrightarrow \mathrm{Cs}(\mathrm{g}) \text { and/or } \mathrm{CsO}_{2} \mathrm{CH}(\mathrm{g}) \\ \text { cesium hydroxide } & 250 & \mathrm{CsOH}(\mathrm{c}) \longrightarrow \mathrm{CsOH}(\mathrm{g}) \\ \text { cesium formate } & 500 & \mathrm{Cs}_{2} \mathrm{CO}_{3}(\mathrm{c})+\mathrm{C}(\mathrm{s}) \longrightarrow \mathrm{Cs}(\mathrm{g}) \\ \text { sludge-frit } & 550 & \mathrm{Cs}_{2} \mathrm{O}(\mathrm{c})+\mathrm{NaCl}(\mathrm{c}) \longrightarrow \mathrm{CsCl}(\mathrm{g}) \\ \text { sludge-frit } & 700 & \mathrm{Cs}_{2} \mathrm{CO}_{3}(\mathrm{~s})+\mathrm{H}_{2} \mathrm{O} \longrightarrow \mathrm{CsOH}(\mathrm{g}) \\ \text { cesium carbonate } & 800 & \mathrm{Cs}_{2} \mathrm{CO}_{3}(\mathrm{l}) \longrightarrow \mathrm{Cs}(\mathrm{g}) \\ \text { sludge-frit } & 1000 & \mathrm{CsBO}_{2}(\mathrm{c}) \longrightarrow \mathrm{CsBO}_{2}(\mathrm{~g})\end{array}$




\section{Acknowledgments}

A significant portion of this work was supported by contract with the Dupont Atomic Energy Division, Savannah River Laboratory (SRL). The siudge and sludge-frit samples were prepared at SRL and were made available by Dennis Bickford. Mr. Art Sessoms and Mr. Marvin Wilke provided valuable technical assistance. 
Berardinelli, S.P. and Kraus, D.L. (1974). Inorg. Chem., 13, 189.

Bickford, D.F. (1985). personal communication.

Bonnel1, D.W. and Hastie, J.W. (1979). "Transpiration Mass Spectrometry of High Temperature Vapors", NBS SP $561,1,357$.

Centnerzwer, M. and Blumenthal, M. (1933). Bull. Intern. Acad.

Polonaise, Class Sci. Math Nat., 499.

Carpenter, J.H., McMullen, J.C. Olmscheid, B.A., Chezick, B.A., and Olig, P.A. (1983). Proc. Second Int. Conf. on Ceramics in Nuclear Waste Management, Am. Ceram. Soc.

Glushko, V.P., Gurvich, L.V., Bergman, G.A., Veits, I.V., Medvedev, V.A., Khachkuruzov, G.A., and Yungman, V.S. 1, (1978), 2, (1979), 3, (1981), 4, (1982). "Thermodynamic Data for Indīvidual Substances.", Aǩad. Nauk SSSR, Inst. Vys. Temp., Moscow, USSR.

Gusarov, A.V. Gorokhov, L.N., and Efimova, A.G. (1967a). Teplofiz Vys. Temp., 5, 584; Eng. Trans., High Temperature $\underline{5}, 524$.

Gusarov, A.V., Gorokhov, L.N., and Efimova, A.G. (1967b). Teplofiz Vys. Temp., 5, 783; Eng. Trans., High Temperature, $\underline{5}, 699$.

Hastie, J.W. and PIante, E.R. (1981). "Mass Spectrometric Studies of MHD Seed-Slag Thermochemistry". Proceeding of Specialists Meeting on Coal $\vec{z}$ ired MHD Power Generation, paper 38, Sydney, Australia. NBSIR 81-2293.

Hastie, J.W., Plante, E.R., and Bonnell, D.W. (1983). "Vaporization of Simulated Nuclear Waste Glass", NBSIR 83-2731.

Hastie, J.W., Zmbov, K.F., and Bonnell, D.W. (1984). High Temp. Science 17, 333 .

Hastie, J.W. and Bonnell, D.W. (1985). High Temp. Science 19, 275.

JANAF (1971 and later editions). Joint Army, Navy, Air Force Thermochemical Tables, 2nd ed., NSRDS-NBS 37, US Gov't Printing Office, Washington, DC

Jantzen, C.M., Bickford, D.F., and Karraker, D.F. (1982). Advances in Ceramics 8, p. 30. Nuclear Waste Management, Ed. G. W. Wicks and W. A. Ross, Am. Ceram. Soc.

Lamoreaux R.H. and Hildenorand, D.L. (1984). J. Phys. Chem. Ref. Data, 13, 151 .

Meisel, T., Halmos, Z., Seybold, K., and Pungor, E. (1975). J. Thermal Analysis, $\underline{7}, 73$.

Nicolosi, S.L., Tang, I., and Munkelwitz, H. (1979). High Temperature Mass Spectrometry study of $\mathrm{Cs}_{2} \mathrm{O}$ and $\mathrm{Rb}_{2} \mathrm{O}$. NUREG/CR-0867, BNL-NUREG-51030. 
Norman J.H. and Staley, H.G. (1966). Fourteenth Annual Conference on Mass Spectrometry and Allied Topics, Dallas, Texas.

Reisman, A. (1958). J. Phys. Chem., 80, 3558.

Schoonmaker, R.C. and Porter, R.F. (1959). J. Chem. Phys., 31, 830. 


\section{Eigure Captions}

1. Comparison of KGA results (open squares, and least squares curve) for apparent $\mathrm{P}(\mathrm{CsOH})$ over $\mathrm{CsOH}(\mathrm{s}, \ell)$ with the JANAE [1971] monomer and dimer data, as labelled.

2. Ratio of $\mathrm{I}^{+} \mathrm{CS} / \mathrm{I}^{+} \mathrm{O}_{2}$ and $\mathrm{I}^{+} \mathrm{CS} / \mathrm{I}^{+} \mathrm{Cs}_{2} \mathrm{O}$ mass spectral ion intensity data from Gusarov et al. [1967a] using an initial condensed phase with composition $\mathrm{Cs}_{2} \mathrm{O}_{2}(\mathrm{c})$. $\mathrm{I}^{+}$is mass spectral ion-intensity in arbitrary units.

3. Comparison of KMS and literature (Lamoreaux and Hildenbrand, 1984) equilibrium constant data for decomposition of $\mathrm{Cs}_{2} \mathrm{O}(\mathrm{g})$ to $\mathrm{Cs}(\mathrm{g})$ and $\mathrm{O}_{2}(\mathrm{~g})$; data obtained from evaporation of $\mathrm{Cs}_{2} \mathrm{O}(\mathrm{l})$ with increasing and decreasing temperature cycles.

4. KGA Cs partial-pressure data, and fitted curves, obtained over $\mathrm{Cs}_{2} \mathrm{CO}_{3}\left(\mathrm{c}, \mathrm{l}\right.$ ) (triangles) and formate-derived $\mathrm{Cs}_{2} \mathrm{CO}_{3}$ (squares) compared with literature data over $\mathrm{Cs}_{2} \mathrm{CO}_{3}$ (Glushko et al. [1978-1982]) and the calculated $\mathrm{Cs}_{2} \mathrm{CO}_{3}+\mathrm{C}$ reaction pressure curve.

5. KMS Cs partial-pressure data, and fitted curve, obtained over $\mathrm{Cs}_{2} \mathrm{CO}_{3}(\mathrm{C}, \mathrm{l})$ (square symbols). Literature curve is from Glushko et al. [1978-1982].

6. Ion-intensity data for the reaction of $\mathrm{Cs}_{2} \mathrm{CO}_{3}(\mathrm{c})$ with $\mathrm{H}_{2} \mathrm{O}$ to form $\mathrm{CsOH}$ at $1010 \mathrm{~K}$ (see reaction $(3.10)$ in text).

7. Comparison of experimental and calculated equilibrium constant data for reaction (3.10) (see text) involving $\mathrm{Cs}_{2} \mathrm{CO}_{3}\left(\mathrm{c}\right.$ ) and $\mathrm{H}_{2} \mathrm{O}(\mathrm{g})$.

8. TMS ion-intensity and approximate partial-pressure data for decomposition of formate-related constituents from sludge.

9. KMS mass spectral ion-intensity and approximate partial-pressure data for relatively low temperature vapor species over the sludge-frit mixture. The partial-pressure scale relates to the species given in parentheses.

10. KMS mass spectral ion-intensity, and approximate partial-pressure data for high temperature vapor species over the sludge-frit mixture. The partial-pressure scale relates to the species given in parentheses.

11. KGA rate of vaporization and apparent vapor pressure data obtained over the sludge-frit mixture for a hypothetical vapor molecular weight of 50 amu.

12. Selected TMS mass spectral ion-intensity and approximate partial-pressure data for high temperature vapor species over the sludge-frit mixture. The partial-pressure scale relates to the species given in parentheses. 


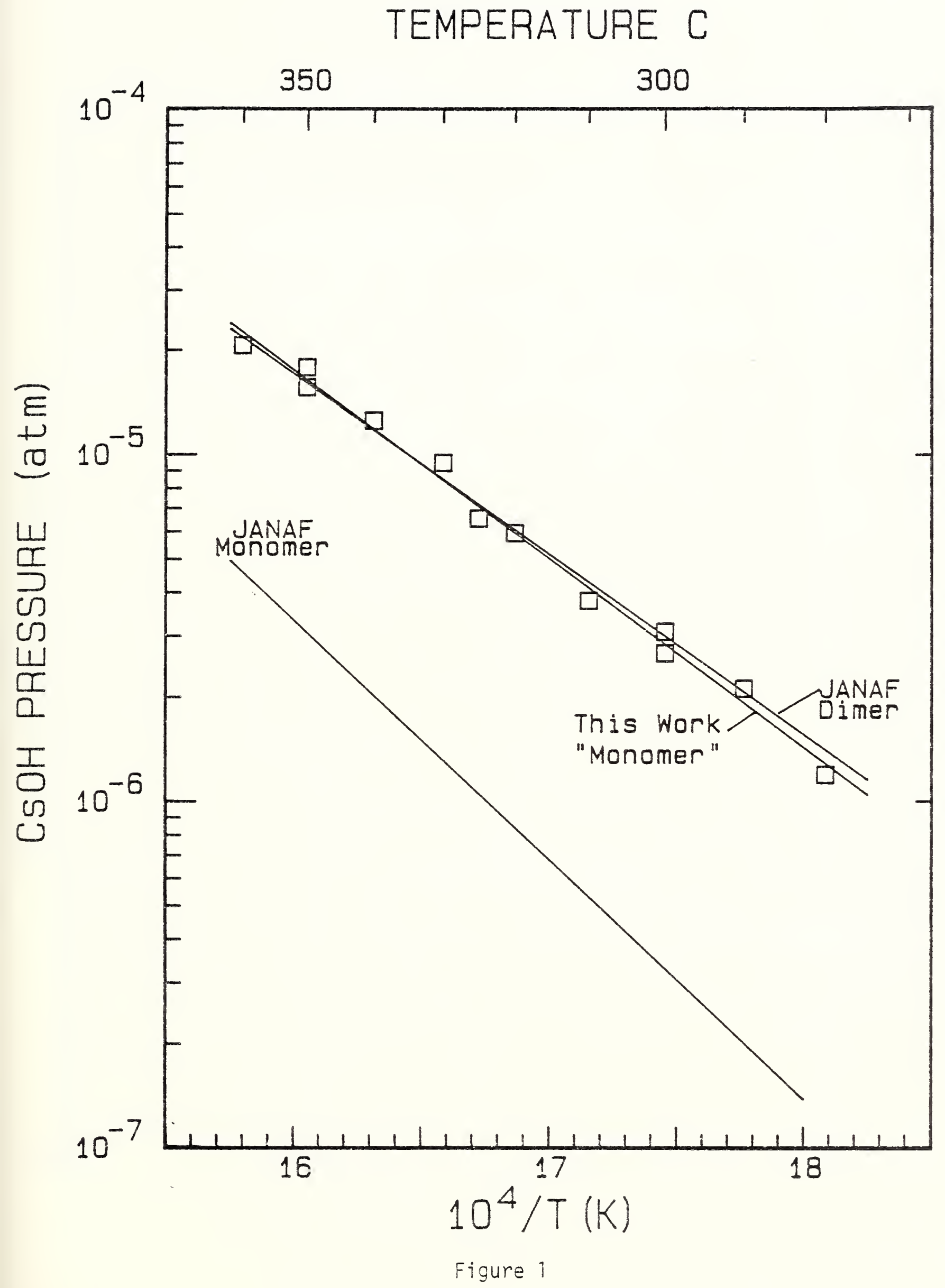




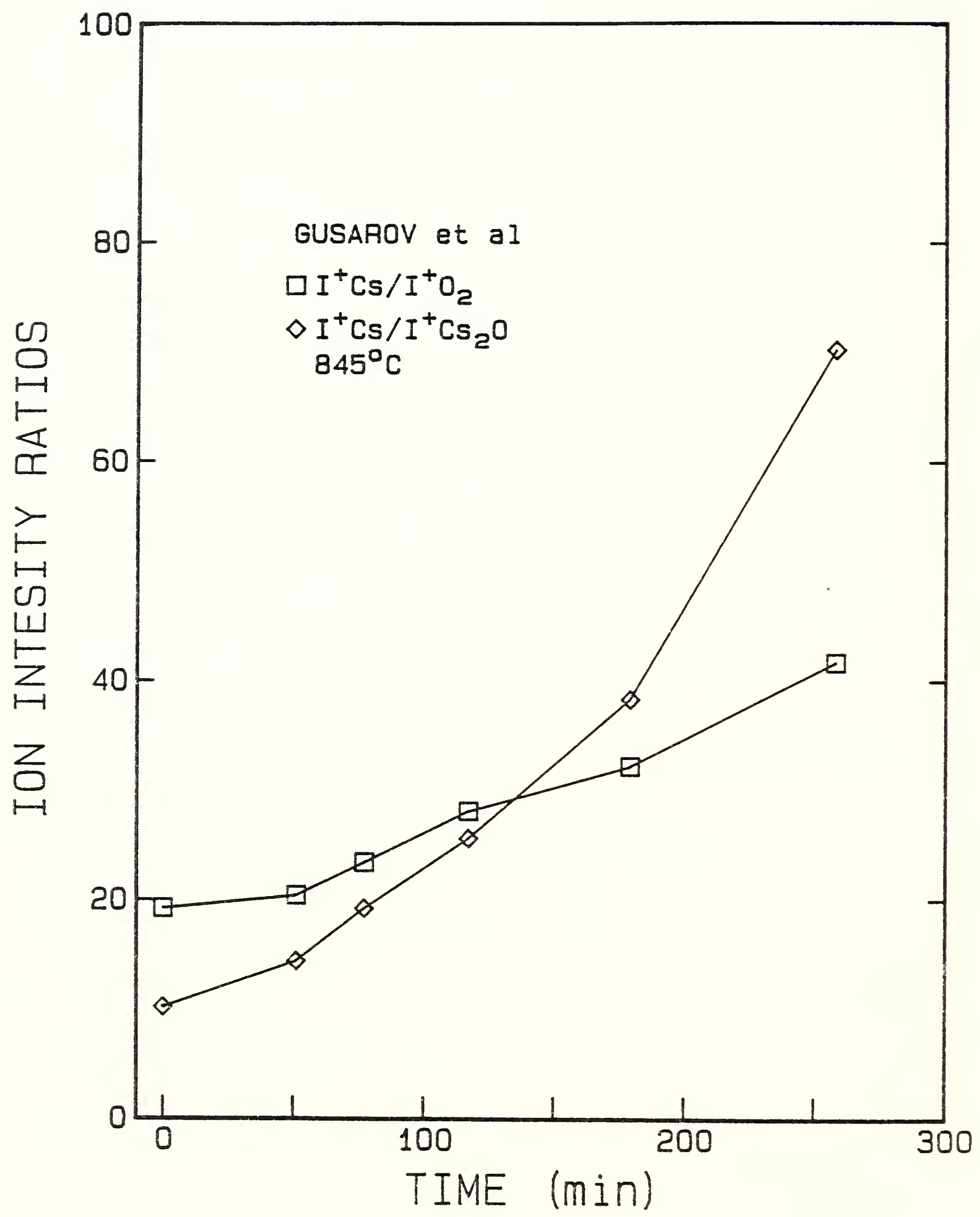

Figure 2 


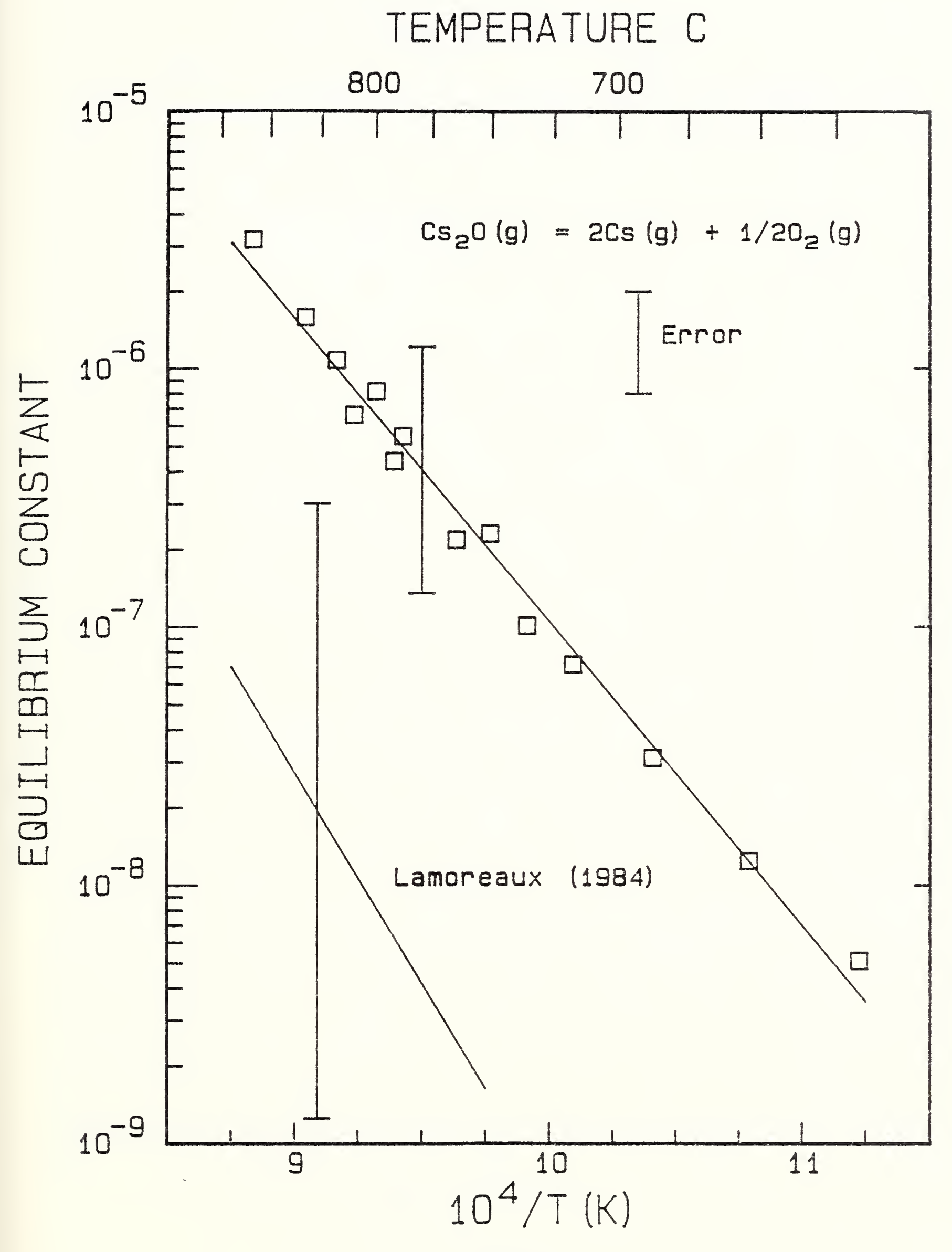

Figure 3 


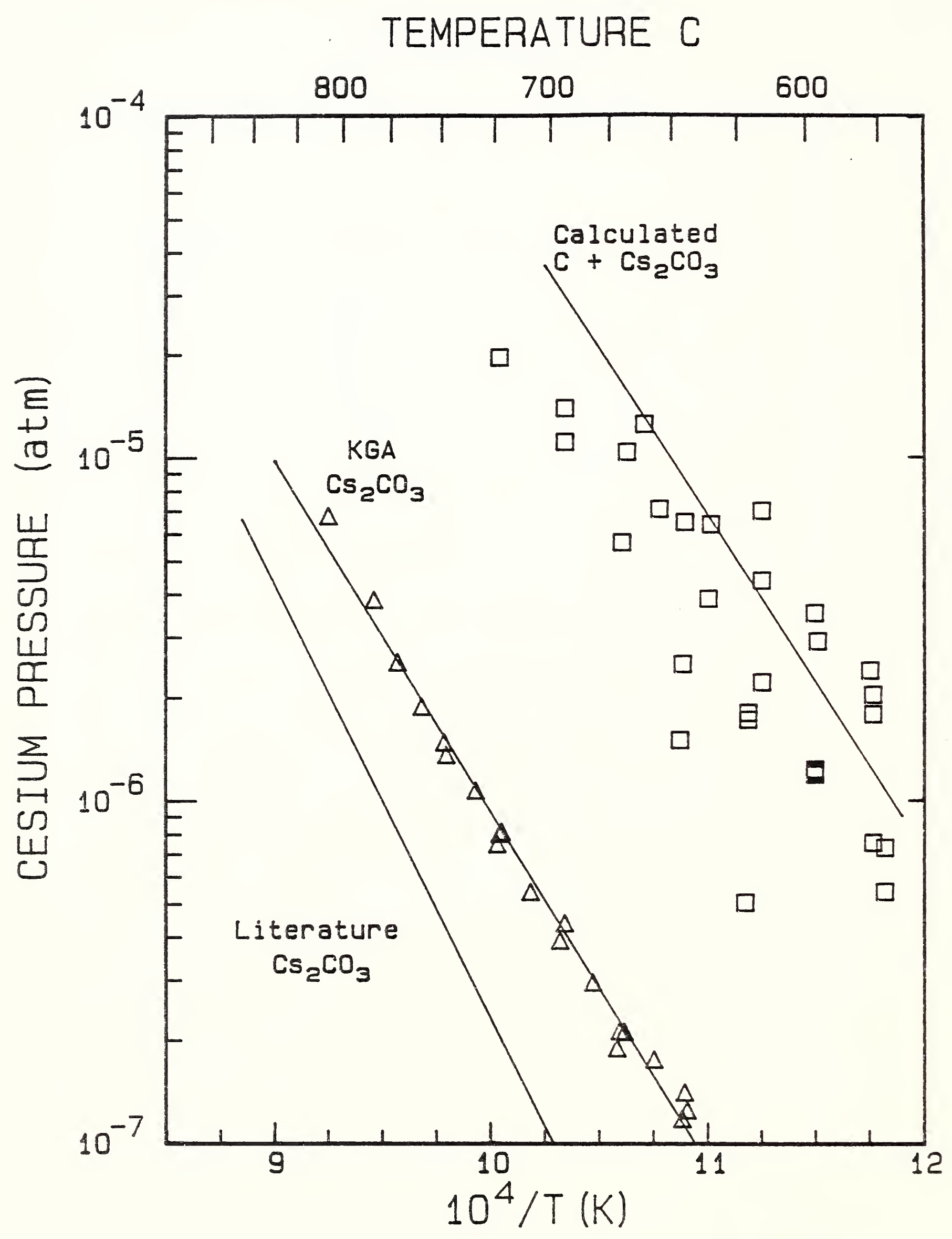

Figure 4 


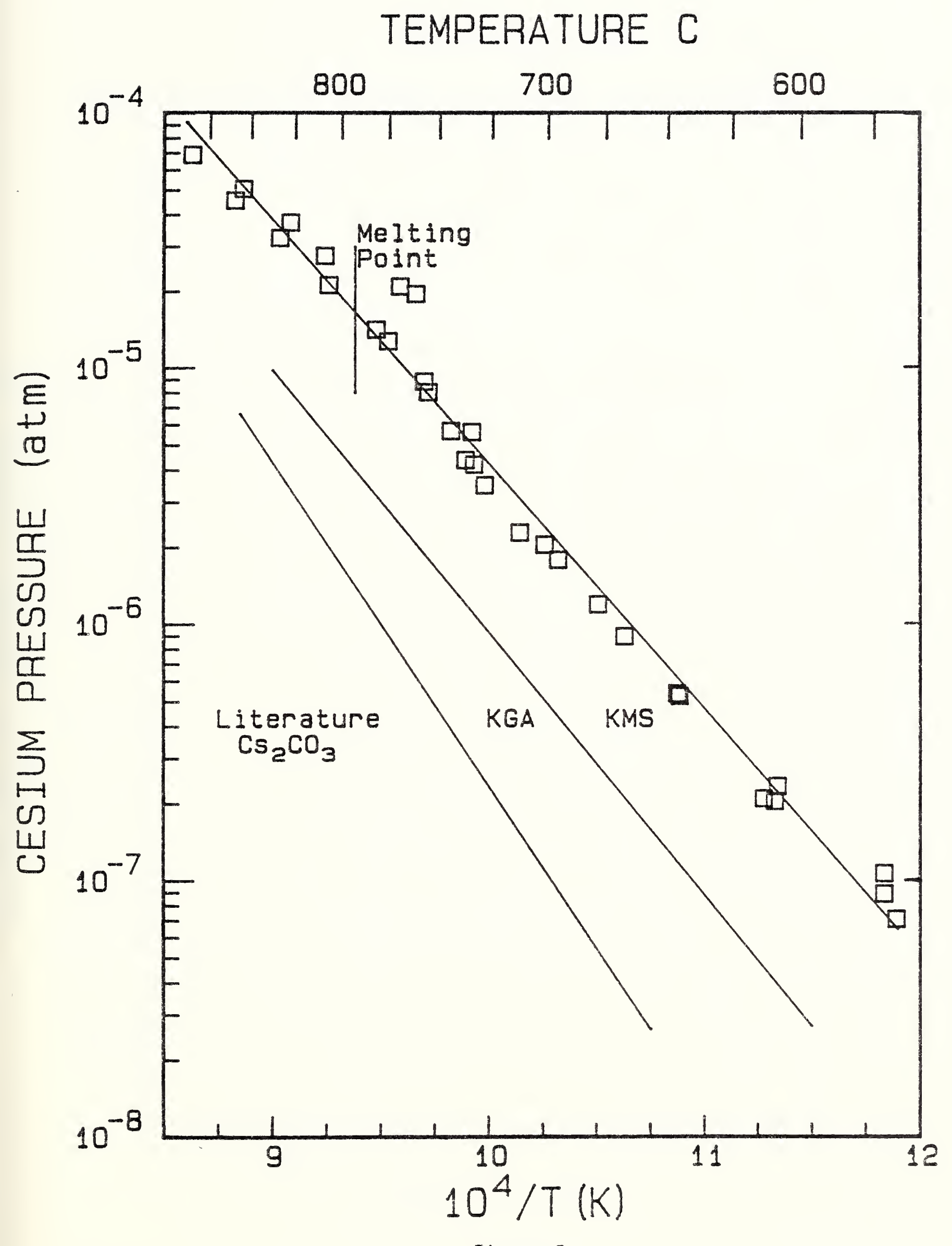

Figure 5 


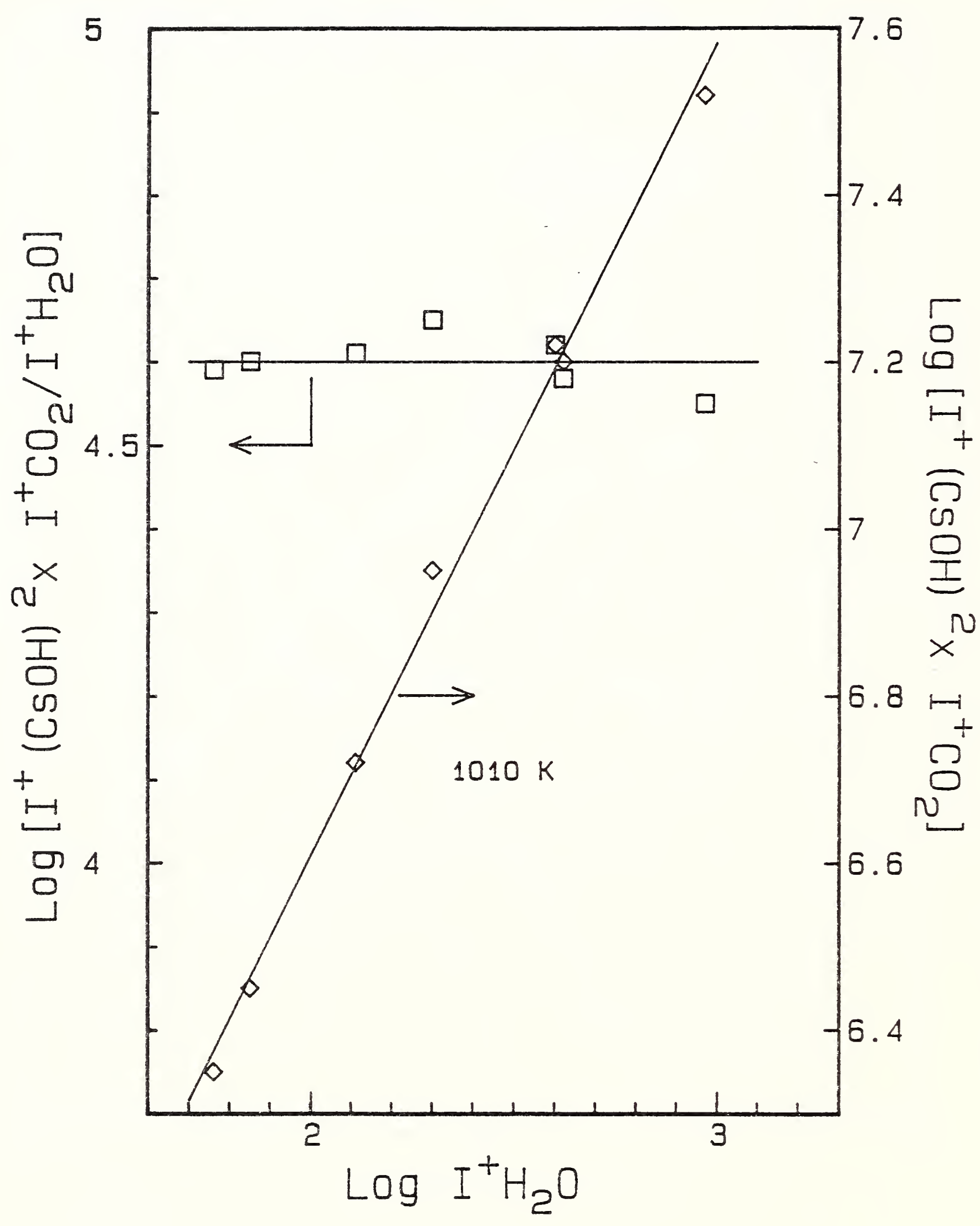

Figure 6 


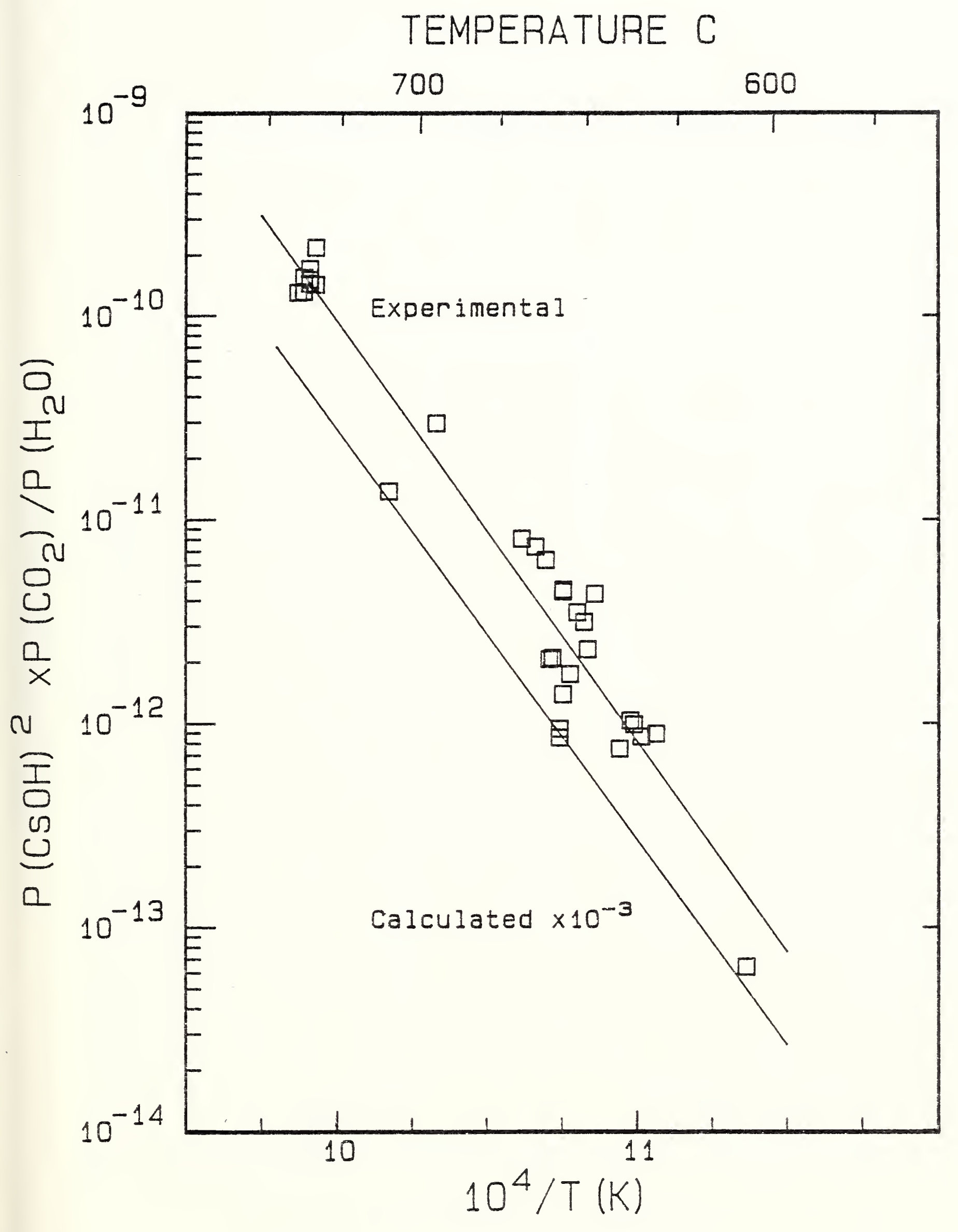

Figure 7 


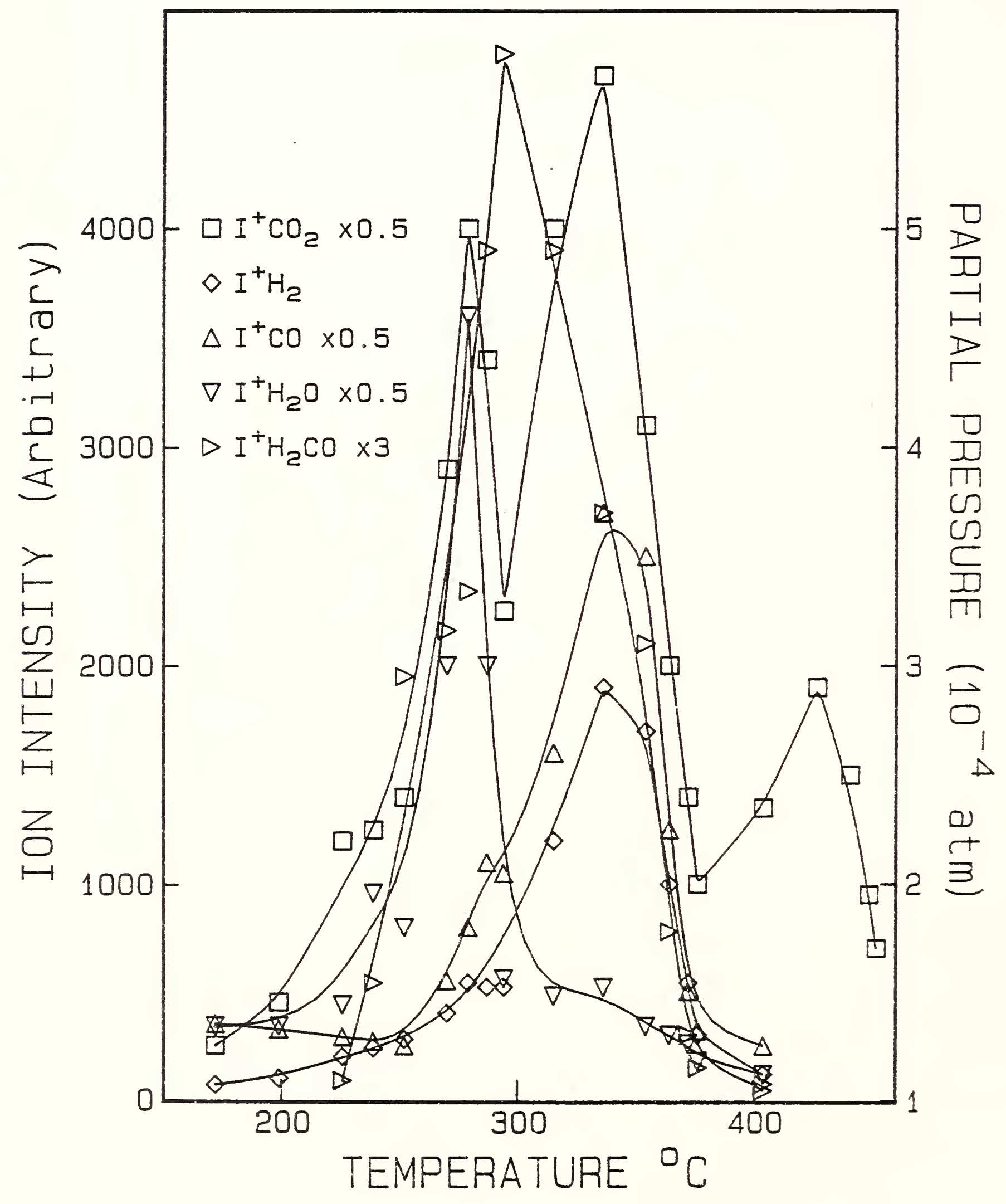

Figure 8 
TEMPERATURE C

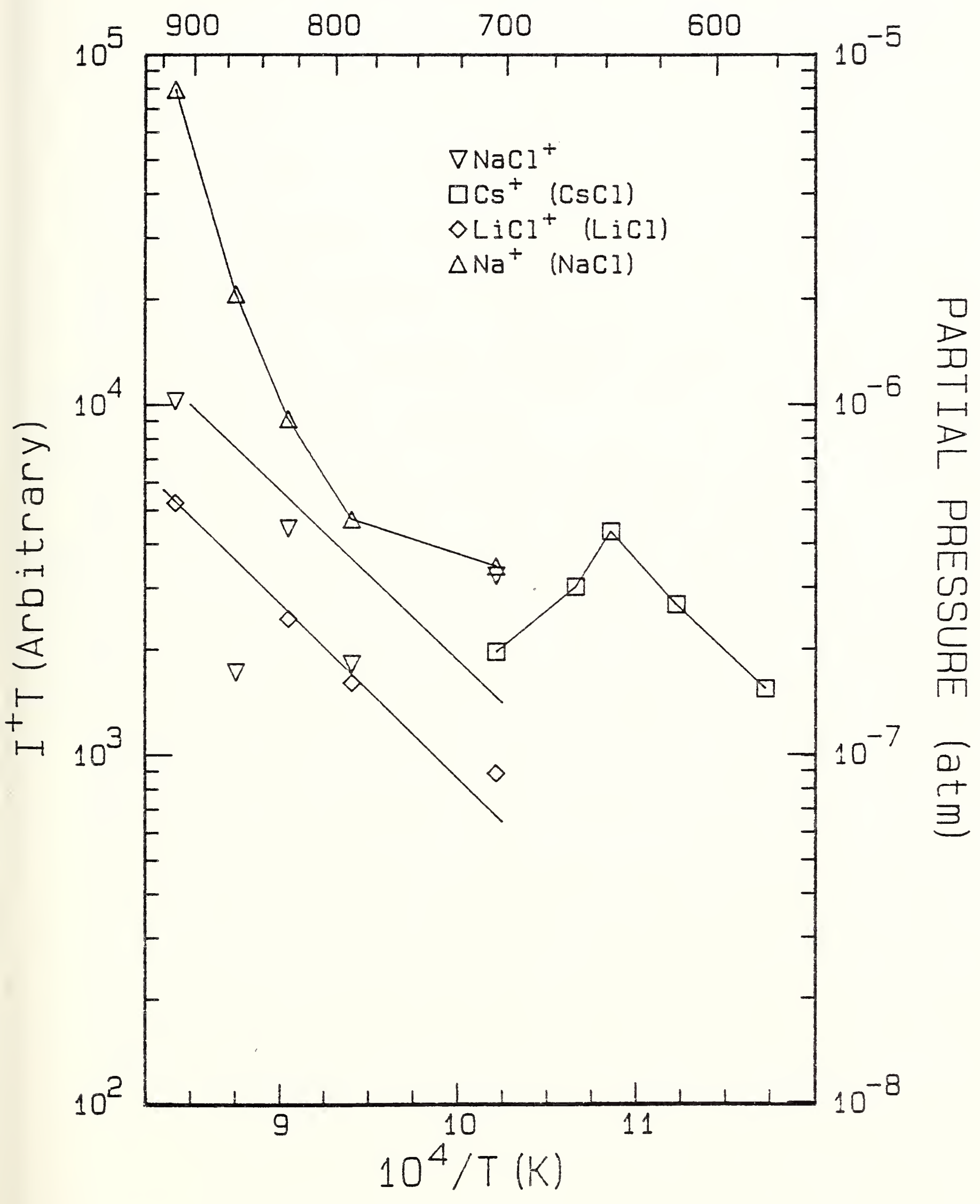

Figure 9 


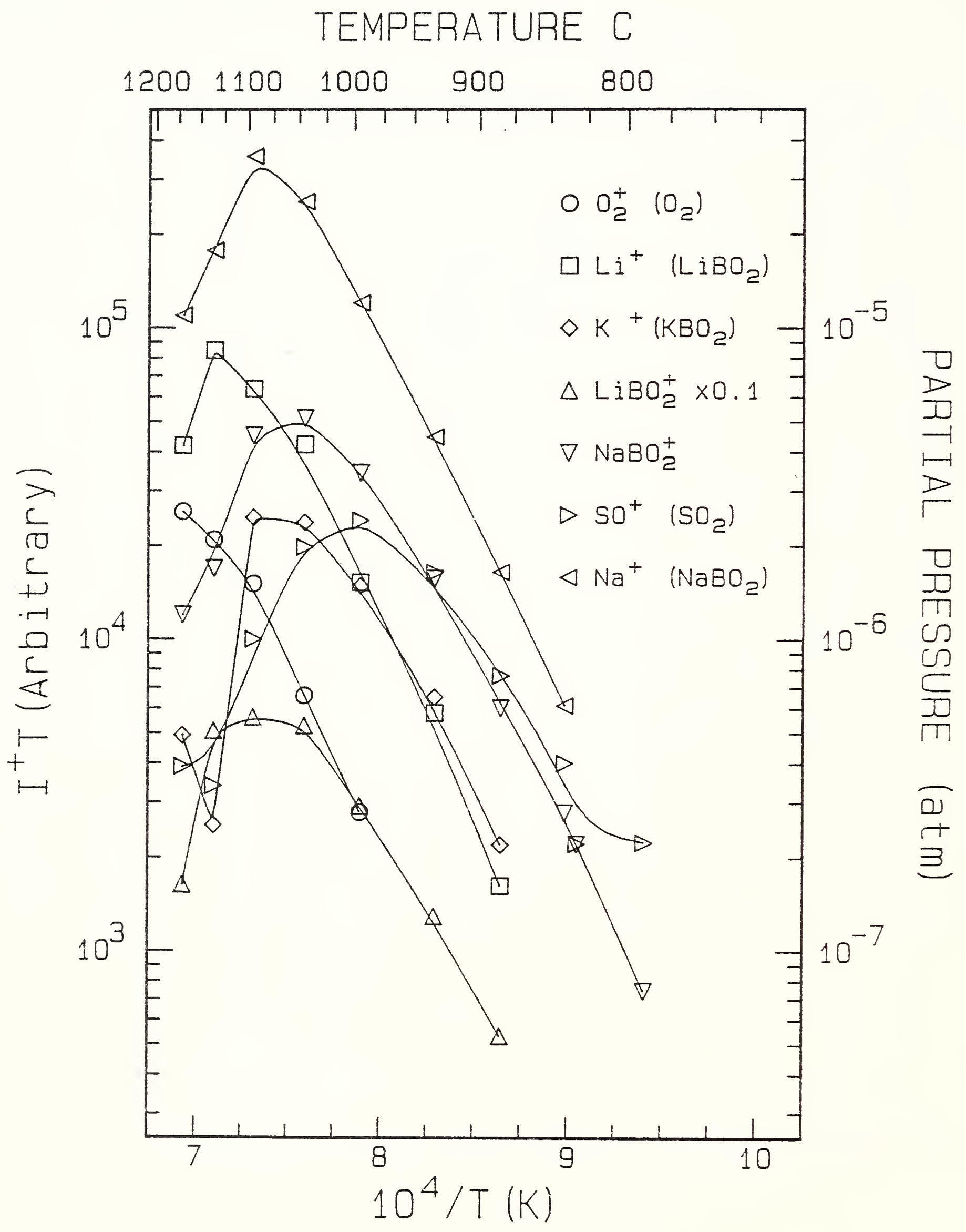

Figure 10 


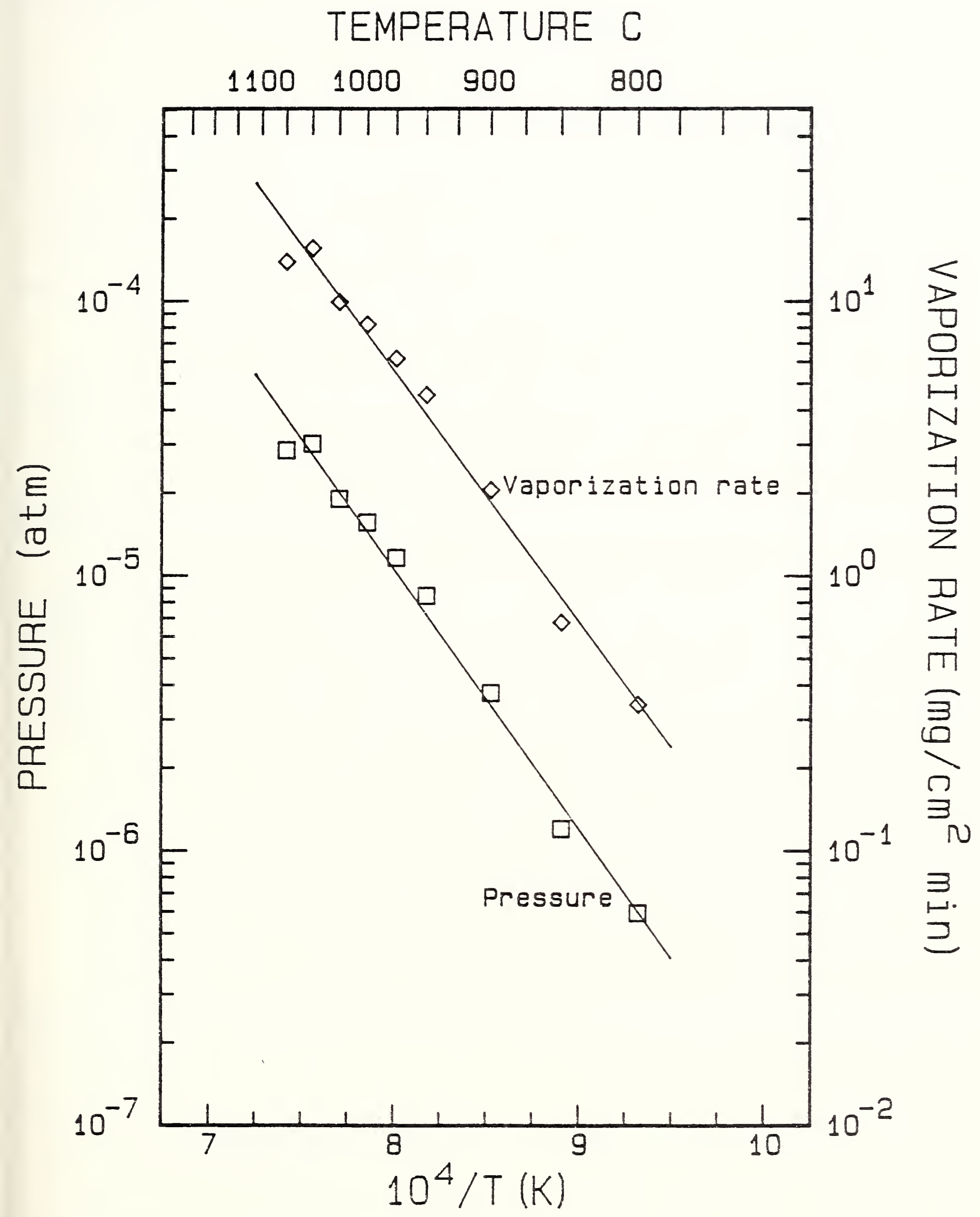

Figure 11 


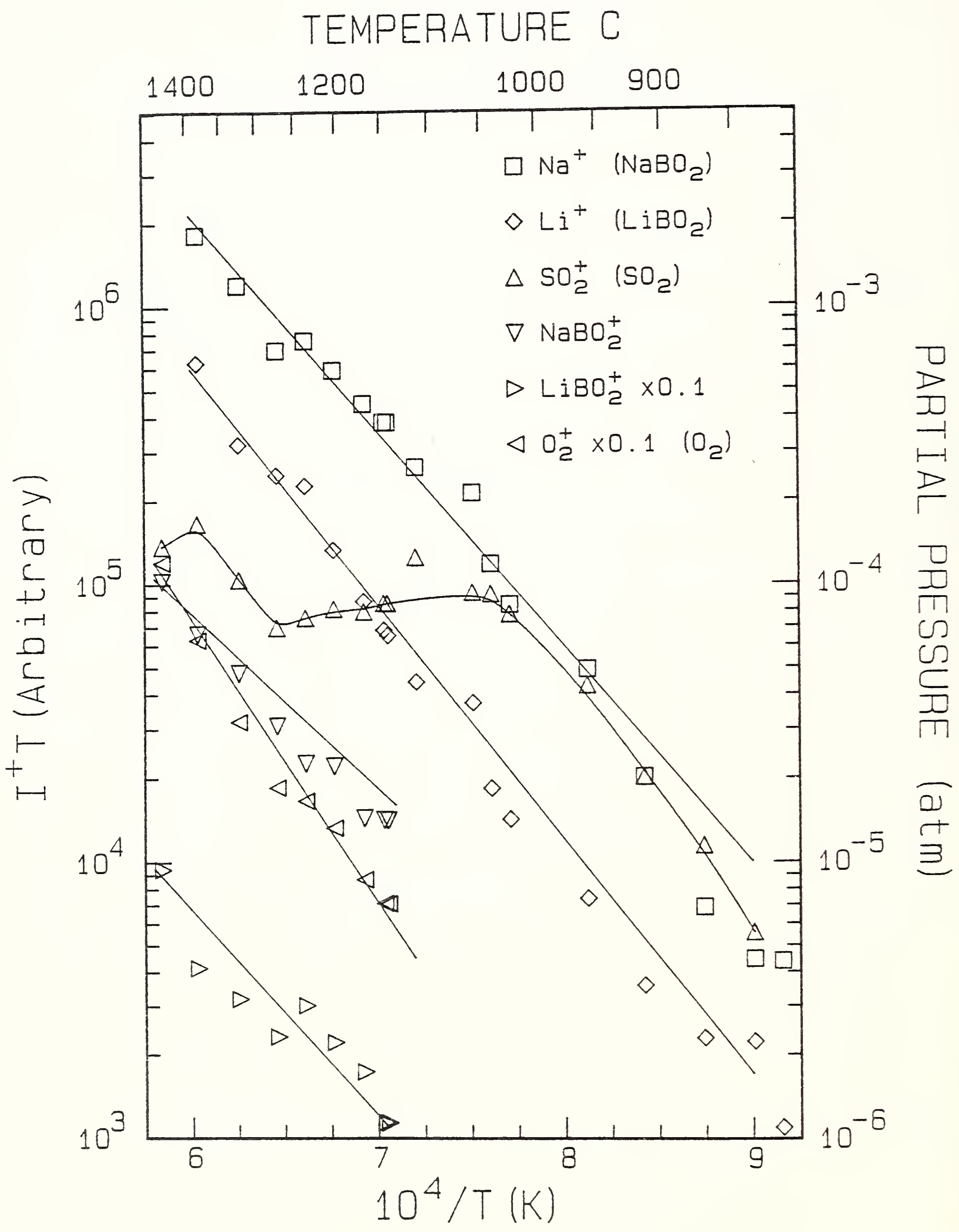

Figure 12 
BIBLIOGRAPHIC DATA

SHEET (See instructions)

4. TITLE AND SUBTITLE

Vaporization and Phase Equilibria of Simulated Radionuclides

\section{5. $A \cup T H O R(S)$}

E.R. Plante and J.W. Hastie

6. PERFORMING ORGANIZATION (If joint or other than NBS, see instructions)

7. Contract/Grant No.

NATIONAL BUREAU OF STANDARDS

DEPARTMENT OF COMMERCE

WASHINGTON, O.C. 20234

8. Type of Report \& Period Covered

Interim Report

9. SPONSORING ORGANIZATION NAME AND COMPLETE ADDRESS (Street, City. State, ZIP)

10. SUPPLEMENTARY NOTES

Document describes a computer program; SF-185, FIPS Software Summary, is aztached.

11. ABSTRACT (A 200-word or less factual summary of most significant information. If document includes a significant bibliography or literature survey. mention it here)

Undesirable losses of radionuclides occur by vaporization during processing of nuclear waste glass. This study examines the phase and chemical transformations that occur during the initial steps of waste incorporation into a borosilicate glass host. Specialized mass spectrometric and thermogravimetric techniques were used to monitor the vapor transport species over a range of temperature and composition. Significant vapor transport of $C s$ was found and its enhancement by the presence of carbon, halogen, and water vapor was also noted.

12. KEY WORDS (Six to twelve entries; alphabetical order; copitalize only proper names; and separate key worcs by semicolons) cesium, mass spectrometry, nuclear waste, thermodynamics, vaporization, CsOH, Cs $\mathrm{C}$ $\mathrm{Cs}_{2} \mathrm{CO}_{3}, \mathrm{CsO}_{2} \mathrm{CH}$

13. AVAILABILITY

$\chi$ Unlimited

For Official Distribution. Do Not Release to NTIS

Z Order From Superintendent of Documents, U.S. Government Printing Office, Washington, D.C. 20402.

14. NO. OF PRINTED PAGES

$$
49
$$

15. Price

X Order From National Technical Information Service (NTIS), Springfield, VA. 22161 


